University of Miami Law School University of Miami School of Law Institutional Repository

1980

\title{
The Third United Nations Conference on the Law of the Sea: the Eighth Session (1979)
}

Bernard H. Oxman

University of Miami School of Law, bhoxman@law.miami.edu

Follow this and additional works at: https://repository.law.miami.edu/fac_articles

Part of the Law of the Sea Commons

\section{Recommended Citation}

Bernard H. Oxman, The Third United Nations Conference on the Law of the Sea: the Eighth Session (1979), 74 Am. Jl. Int'l. Law 1 (1980).

This Article is brought to you for free and open access by the Faculty and Deans at University of Miami School of Law Institutional Repository. It has been accepted for inclusion in Articles by an authorized administrator of University of Miami School of Law Institutional Repository. For more information, please contact library@law.miami.edu. 


\title{
THE THIRD UNITED NATIONS CONFERENCE ON THE LAW OF THE SEA: THE EIGHTH SESSION (1979)
}

\author{
By Bernard H. Oxman *
}

\section{INTRODUCTION}

The eighth session of the Third United Nations Conference on the Law of the Sea met in Geneva from March 19 to April 27, 1979. It resumed in New York from July 16 to August 24, 1979, with the first three days devoted to informal consultations. ${ }^{x}$

Intensive substantive work on major outstanding issues began on the first day and continued, almost without interruption, throughout both parts of the session. The fruits of these labors are recorded in a revision of the Informal Composite Negotiating Text (ICNT/Rev.1) issued following the last plenary meeting in Geneva, ${ }^{2}$ and in texts contained in reports of the relevant chairmen presented at the close of the session in New York. ${ }^{3}$ At

- Associate Professor of Law, University of Miami School of Law. United States Representative and Vice Chairman of the U.S. delegation, and Chairman of the English Language Group of the Drafting Committee, at the eighth session of the Law of the Sea Conference. The views expressed herein are those of the author and do not necessarily represent the views of the Department of State, the U.S. Government, or the English Language Group or Drafting Committee of the conference.

1 This article is a sequel to Stevenson \& Oxman, The Preparations for the Law of the Sea Conference, 68 AJIL 1 (1974); The Third United Nations Conference on the Law of the Sea: The 1974 Caracas Session, 69 AJIL 1 (1975);-The 1975 Geneva Session, 69 AJIL 763 (1975); and Oxman, The Third United Nations Conference on the Law of the Sea: The 1976 New York Session, 71 AJIL 247 (1977);-The 1977 New York Sessions, 72 AJIL 57 (1978);-The Seventh Session (1978), 73 AJIL I (1979).

2 UN Doc. A/CONF.62/WP.10/Rev.1 (April 28, 1979), reprinted in 18 ILM 686 (1979). For discussions of the regime of straits under the revised ICNT, see the articles by W. Michael Reisman and John Norton Moore, infra at pp. 48 and 77, respectively. Professor Moore's analysis is consistent with the author's recollections and previous articles, and should put the matter to rest.

${ }^{3}$ The Official Records of the conference (hereinafter cited as OFF. REc.) for the eighth session were not available at the time of preparation of this article. Reports to the Plenary of the Conference, UN DOC. A/CONF.62/91 (Sept. 19, 1979) and Corr.1 (Oct. 15, 1979), includes all of the following: Report of the General Committee as approved by the Conference, UN Doc. A/CONF.62/88 (Aug. 24, 1979) at 3; Report to the Plenary by the Chairman of the First Committee, UN Doc. A/CONF.62/L.43 (Aug. 29,1979 ) at 8 ; Report on Negotiations held by the Chairman and the Co-ordinators of the Working Group of 21, UN Doc. A/CONF.62/C.1/L.26 (Aug. 21, 1979) at 16 [hereinafter cited as WG21 report] (the chairman and coordinators are respectively the chairman of the First Committee and the chairmen of Negotiating Groups 1 and 2; the Report of the Chairman of the Group of Legal Experts on the Settlement of Disputes Relating to Part XI is included in App. B at 64); Report to the Plenary Conference by the Chairman of the Second Committee, UN Doc. A/CONF.62/L.42 (Aug. 24, 1979) at 70, including a summary of his report on Negotiating Group 6, Conf. Doc. NG6/19 (Aug. 22, 1979); Report of the Chairman of Negotiating Group 7, Conf. Doc. NG7/45 (Aug. 
that time the conference adopted a work plan for the ninth session which anticipates completing the informal proceedings, adopting a formal text, and concluding formal proceedings on that text.4 The session is scheduled to meet in the spring and summer of 1980.

The difficult, at times painful, and frequently thankless task of confronting and resolving outstanding issues in detail, one by one, in myriad groups, has advanced to a degree not fully appreciated. A "package" that emerges in this way stirs little drama, at least until the combined impact is suddenly perceived, as happened in the closing hours at Geneva when the conference debated the revisions to the ICNT presented by the chairmen. Yet the determination to succeed evident in this work, more than any rhetorical manifestation of that determination, provides the substantive foundation for the optimistic timetable adopted for the ninth session.

The work of the conference has, of course, been cumulative. The eighth session in particular is best understood by reference to the orgenization of work of the preceding session, ${ }^{5}$ where seven negotiating groups on outstanding hardcore issues were appointed. ${ }^{6}$ At the seventh session the conference decided that revisions in the Informal Composite Negotiating Text (ICNT) ${ }^{7}$

should not be introduced on the initiative of any single person . . . unless presented to the Plenary and found, from the widespread and substantial support prevailing in Plenary, to offer a substantially improved prospect of a consensus. The revision ... should be the collective responsibility of the President and the Chairmen of the main committees, acting together as a team headed by the President. The Chairman of the Drafting Committee and the Rapporteur-General should be associated with the team. ... ${ }^{8}$

While the ICNT was not revised at the seventh session, new texts were presented in reports by the chairmen of the main committees and negotiating groups. ${ }^{\circ} \quad$ Moreover, most of the substantive articles that were not assigned

22, 1979) at 116; Report by the Chairman of the Third Committee, UN Doc. A/CONF. 62/L.41 (Aug. 23, 1979) at 75; Report of the President of the Conference on the Work of the Informal Plenary on Final Clauses, UN Doc. A/CONF.62/L.44 (Aug. 27, 1979) at 125; Report by the Chairman of the Group of Legal Experts on Final Clauses, Conf. Doc. FC/16 (Aug. 23, 1979) at 121; Report of the President of the Conference on the Work of the Informal Plenary on the Settlement of Disputes, UN Doc. A/CONF. 62/L.45 (Aug. 29, 1979); Report to the Plenary by the Chairman of the Drafting Committee, UN Doc. A/CONF.62/L.40 (Aug. 22, 1979) at 81. The documents of the eighth session are reproduced in English in Dokumente der DRTTEN SEEnEchtskonfERENZ der Vereinten Nationen-Genfer Session 1979 (ed. Platzöcler, Munich: Stiftung Wissenschaft und Politik, June 1979, 3 vols., SWP-M2128/I-III),-NEW YORKER SESSTON 1979 (Oct. 1979, 2 vols., SWP-M2291/I-II).

4 Report of the General Committee, note 3 supra, at 3.

5 UN Doc. A/CONF.62/62 (April 13, 1978), 10 OFf. Rec. 6 (1978); see Oxman, The Seventh Session, note 1 supra, at 3-5.

${ }^{6}$ Text of para. II(5) of UN Doc. A/CONF.62/62, note 5 supra, reproduced in 73 AJIL 5 n.14 (1979).

i UN Doc. A/CONF.62/WP.10 (July 15, 1977) and Add.I (July 22, 1977), 8 OrF. Rec. 1 (1978), reprinted in 16 ILM 1108 (1977).

${ }^{8} \mathrm{UN}$ Doc. A/CONF.62/62, note 5 supra, pt. II, paras. 10 and 11.

9 UN Doc. A/CONF.62/RCNG/1 and 2, 10 OFF. REc. 13, 126 (1978) see Oxman, The Seventh Session, note 1 supra, 73 AJIL 1 (1979) passim. 
to negotiating groups were subjected to, and survived, an article-by-article review in the Second Committee.

The eighth session began where the seventh left off, with the benefit of additional reflection and discussion during the intervening period. It based its work on the procedures already agreed, together with additional procedural innovations on matters dealt with by the First Committee. Substantive matters tentatively agreed at the seventh session or before were largely left alone. On deep seabed mining in particular, the conference faced up to, and in effect rejected, attempts either to reopen issues long since settled or to revert to the kind of ideological debate characteristic of its early sessions. This attitude is significant evidence of a desire to do the work necessary to conclude the negotiations, particularly because there were new members on some delegations who might have been sympathetic to reopening issues on which they had not worked themselves.

\section{Results of the Session}

The substantive results of the eighth session can be divided into four categories.

First, those texts substantially completed and submitted in the chairmen's reports at the seventh session were incorporated into the ICNT/ Rev.I. Thus, the ICNT/Rev.1 generally records the completion of informal negotiations on these matters, subject of course to discussion of drafting questions, including problems of conformity of texts.

This category includes the texts prepared in Negotiating Group 4 on access of landlocked states and "states with special geographical characteristics" to surplus fisheries of the economic zones of their neighbors, ${ }^{10}$ the amendments prepared in Negotiating Group 5 on settlement of disputes with respect to fisheries, ${ }^{11}$ an amendment on anadromous species prepared by the Second Committee, ${ }^{12}$ the substantial amendments prepared by the Third Committee on protection and preservation of the marine environment, ${ }^{13}$ and its amendments to Part XIV, "Development and Transfer of Marine Technology," ${ }^{14}$ and a drafting correction proposed by Nego-

I0 ICNT/Rev.1, Arts. 62, 69, and 70. Negotiating Group 4 Reports at 10 OFF. REc. 88-95, 166-67 are discussed by the author in 73 AJIL at pp. 16-18.

11 ICNT/Rev.1, Arts. 296(1) and (3) and 297. Negotiating Group 5 Reports at 10 OFF. Rec. 117-23, 168-69 are discussed by the author in 73 AJIL at pp. 18-19.

1: ICNT/Rev.l, Art. 66. Second Committee Report, para. 13, 10 OFF. REc. 85-86.

13 ICNT/Rev.1, Arts. 1(5), 194(5), 210(5), 211(1), (3), (4) and (7), 212(1), $220(2),(5)$ and $(6), 221,226,230$, and 235 . The last of these was prepared at the eighth session. Third Committee Reports on part XII at 10 OfF. Rec. 96-115, 173-97 are discussed by the author in 73 AJIL at pp. 24-27.

14 In his report at the end of the eighth session, the chairman of the Third Committee repeats the conclusion that "the substantive negotiations on Part XII (Protection and Preservation of the Marine Environment) and Part XIV (Development and Transfer of Marine Technology) could be considered as completed." UN Doc. A/CONF.62/L.41, note 3 supra. The use of the term "substantive negotiations" presumably reflects the fact that these texts will need to be harmonized with relevant First Committee and 
tiating Group 7 regarding delimitation of the territorial sea between states with opposite or adjacent coasts. ${ }^{15}$ Internal cross-references in the ICNT/ Rev.1 are based on the relevant discussions of the Drafting Committee, which reflect a general trend toward simplicity (e.g., use of "this Convention" rather than "the present Convention").16

Second, the ICNT/Rev.I contains new texts prepared at the eighth session, although based in part on the work of the seventh session. The new texts, while presenting some problems that remain to be addressed, in effect either reflect agreements reached or provide a substantially advanced basis for agreement. This category includes the precise definition of the limits of the continental shelf ${ }^{17}$ and new rates of reveriue sharing from the continental shelf where it extends beyond 200 miles, ${ }^{18}$ as well as the many new provisions in part XI on deep seabed mining beyond the limits of the continental shelf. The acceptability of these texts depends to some extent on additional work on related matters.

Third, the reports issued at the end of the eighth session contain texts that substantially resolve or provide the basis for resolving a number of issues that remain in the ICNT/Rev.l. The most comprehensive is the report dealing with deep seabed mining issues. ${ }^{19}$ It includes proposed amendments to the ICNT/Rev.1 on the system of exploration and exploitation, the financial arrangements, the Assembly and Council of the Seabed Authority, and the settlement of disputes. With some important exceptions such as voting in the Council, the new texts mark a substantial advance toward final agreement on deep seabed mining.

The report of the chairman of the Third Committee ${ }^{20}$ on marine scientific research also falls in this category. It contains amendments to the ICNT/Rev.I that resulted from intensive negotiations. While some drafting work remains, issuance of these texts largely brings the difficult substantive negotiations on this matter to a close.

While the report of the Second Committee ${ }^{21}$ is cautious, two matters referred to in it belong in the third category. In New York, the committee accepted an amendment negotiated among concerned delegations that was designed to eliminate a problem created by the the introduction of an amendment into the ICNT/Rev.1 regarding suspension of innocent passage. ${ }^{22}$ An amendment on protection of marine mammals also nego-

Second Committee texts and perhaps redrafted in some respects by the Drafting Committee, which may not undertake substantive negotiations. Rules of Procedure, rule 53, UN Doc. A/CONF.62/30/Rev.2.

15 ICNT/Rev.1, Art. 15. See Negotiating Group 7 Report at 10 OFF. Rec. 124.

16 Drafting Committee Informal Paper 1/Rev.1/Add.2 (Aug. 31, 1979); see Report by the Chairman of the Drafting Committee, UN Doc. A/CONF.62/L.i9 (June 15, 1979), 10 OFF. REc. 199, and ICNT/Rev.I (explanatory memorandum).

17 ICNT/Rev.1, Art. 76.

19 WG21 report, note 3 supra. 18 Id., Art. 82(2).

21 Ibid.

22 ICNT/Rev.1, Art. 25, pursuant to a Belgian proposal designed to deal with artillery exercises of the coastal state, added protection for the safety of ships as a permissible basis for costal state suspension of innocent passage. The vagueness of this 
tiated among concerned delegations would seem to provide a basis for a final draft. ${ }^{23}$ Similarly, Negotiating Group 7 reports substantial, albeit conditional, agreement on a text dealing with provisional arrangements and self-restraint pending delimitation of the economic zone or continental shelf between states with opposite or adjacent coasts. ${ }^{24}$

The most speculative use of the word "results" characterizes the fourth, and final, category. With respect to deep seabed mining, negotiations on the interim production limitation continued until the last day. The "results," while not included in a report, would seem to provide a basis for successful completion of consultations among the principal consumers and producers of the metals involved. There was widespread support in the Informal Plenary on Final Clauses for the establishment of a preparatory commission to prepare necessary rules and regulations for deep seabed mining, and to undertake other preparations for the Seabed Authority, perhaps including arrangements for training. With respect to settlement of disputes regarding delimitation between states with opposite or adjacent coasts, the view is now widely held that compulsory conciliation on

language proved objectionable. Previous texts provided for coastal state suspension only where "essential for the protection of its security," based on the rule in the Convention on the Territorial Sea and the Contiguous Zone, 1958, Art. 16, para. 3, 15 UST 1606, TIAS No. 5639, 516 UNTS 205, reprinted in 52 AJIL 834 (1958). As a result of consultations, the addition in the ICNT/Rev.1 would be replaced by adding the words "including weapons exercises" of the coastal state after the reference to "its security."

$\approx$ The main purposes of the amendment are to avoid a possible misreading of the text by making clear that Article 65 was never intended to permit less restrictive limitation or regulation of the exploitation of marine mammals than would be required by the convention if there were no such article, and to direct particular attention to the need for appropriate organizational arrangements for the protection of cetaceans. Article 65 appears in Part V, "Exclusive Economic Zone," and is incorporated by reference by Article 120 into Part VII, Section 2, "Management and Conservation of the Living Resources of the High Seas." An examination of the amendment, superimposed on the ICNT text of Article 65 by italicizing the additions and adding square brackets around deletions, might prove illuminating in this context:

Nothing in this Part [Convention] restricts the right of a coastal State or the competence of an international organization, as appropriate, to prohibit, limit or regulate [regulate and limit] the exploitation of marine mammals more strictly than provided for in this Part. In this connexion, States shall cooperate [either directly or through appropriate international organizations] with a view to the conservation [protection and management] of marine mammals and in the case of cetaceans shall in particular work through the appropriate international organizations for their conservation, management and study.

The main question raised relates to the words, "In this connexion."

It should also be noted that the chairman of the Third Committee reported a consensus on the understanding that the term "marine environment" includes marine life. 10 OfF. Rec. 97 (1978). ICNT/Rev.1, Article 192 provides, "States have the obligation to protect and preserve the marine environment."

is Note 3 supra. The amended text of Articles 74, paragraph 3 and 83, paragraph 3 would read:

Pending agreement as provided for in paragraph 1 the States concerned, in a spirit of understanding and co-operation, shall make every effort to enter into provisional arrangements of a practical nature and, during this transitional period, not to jeopardize or hamper the reaching of the final agreement. Such arrangements shall be without preiudice to the final delimitation. 
some aspects, rather than arbitration or complete elimination of compulsory third-party procedures on all aspects, represents the basis for accommodation both on the merits and because the negotiations on substantive delimitation principles are unlikely to yield a precise, definitive rule.

\section{Outstanding Issues}

As a result of these accomplishments, for the first time it is possible to risk suggesting a list of major outstanding substantive issues for the ninth session that is at once precise and comprehensive. Any such list proceeds from the assumption that the hundreds of issues regarded as settled will not be reopened, particularly during formal proceedings, and that remaining "drafting" or "technical" problems-especially on deep seabed mining, marine mammals, and marine scientific research-may take a little time to resolve but will not become major issues. This being said, the list can be divided into groups of issues as follows.

Deep Seabed Mining. The United States delegation, in its report on the resumed eighth session, identified the following 13 items as the most important problems remaining in the deep seabed mining provisions:

(1) Article 140: sharing of benefits with "peoples who have not attained full independence or other self-governing status";

(2) Article 150: making clear that the provisions on policies relating to activities in the Area shall be implemented as specifically provided in this part;

(3) Article 151: agreement on the numbers in the production ceiling;

(4) Article 155, paragraph 6: the moratorium;

(5) Article 161: voting in the Council (including Article 162, paragraph 2(j));

(6) Article 188: providing access to commercial arbitration for contractual disputes;

(7) Annex II, Article 4: sponsorship where nationality and control are separated;

(8) Annex II, Article 5 on technology transfer: the Brazil clause, ${ }^{25}$ time limits, dispute settlement recourse for third-party owners, and avoidance of warranty implications;

(9) Annex II, Article 7 on selection of applicants: the priority accorded the Enterprise by paragraph 4;

(10) Annex II, Article 10 on joint arrangements: the failure to make clear that they have the same security of tenure as other contracts;

(11) Annex II, Articles 10 or 11 on payments by the Enterprise: the failure to state that the Enterprise is liable for the same payments as the contractors, at least with respect to activities in nonreserved sites;

${ }^{25}$ Annex II, Art. 5, para. 1(e) imposes the same obligation to transfer technology to a developing country applying for a mining contract as the obligation to transfer technology to the Enterprise. 
(12) Annex III, Article 10 on financing the Enterprise: the failure to require that payments and guaranties be in convertible currencies; and

(13) Annex III, Article 12: tax immunity for the Enterprise. ${ }^{26}$

The Continental Shelf. The remaining issues, while technical, are important to some of those principally concerned with the continental shelf where it extends seaward of 200 miles from the coast:

(1) ridges;

(2) Sri Lanka's proposal for a special approach to determining the extent of its continental margin;

(3) the composition, functions, and procedures of the proposed Commission on Limits of the Continental Shelf, including arrangements in the event the coastal state has difficulty accepting the commission's initial reactions to coastal state charts; and

(4) the exemption of developing coastal state importers from the obligation to contribute revenues derived from continental shelf mineral exploitation beyond 200 miles.

Delimitation of the Economic Zone and Continental Shelf Between States with Opposite or Adjacent Coasts. The major issues in this category are:

(1) the substantive principles governing delimitation, including related matters such as the question of the right of a state to file a definitive declaration of interpretation of these principles; and

(2) the scope of compulsory conciliation of delimitation disputes.

In addition to these items, the conférence will now focus increasingly on matters customarily left until the end, such as final clauses and drafting, on which problems of substantive and political importance have already arisen. At the eighth session, intensive work on final clauses was undertaken for the first time. It is still too soon to tell how difficult the problems identified by the Informal Plenary on Final Clauses will prove, but some are troublesome and could preclude agreement. They will be addressed later in this article.

The Drafting Committee intensified its labors at the eighth session; it issued its first set of recommendations on harmonization of texts ${ }^{27}$ and is preparing a second. ${ }^{28}$ The article-by-article review facing the Drafting Committee and its Language Groups is an awesome task that will require a great deal of time and effort, primarily because the provisions of the ICNT were drafted by different people at different times using different models

: U.S. Delegation Report, Resumed Eighth Session of the Third United Nations Conterence on the Law of the Sea, New York, July 16-August 24, 1979 (unpublished). Other delegations, of course, might add some items to this list of deep seabed mining issues. The French delegation, for example, is unhappy with the text of the so-called antimonopoly clause (Annex I, Art. 6, para. 3(d)). Nevertheless, the U.S. delegation's list is indicative of the nature and extent of the remaining problems.

27 Note 3 supra.

2* It deals with Drafting Committee Informal Paper 2/Add.1. 
under different circumstances. They enjoyed neither the stable and limited composition nor the traditional use of a special rapporteur that characterize the International Law Commission (though at times they copied texts from the 1958 conventions). The most controversial and important provisions were frequently "frozen" the moment even tentative agreement emerged, on the oft-repeated assurance that drafting problems would be handled later.

These problems will be resolved as the conference faces its last and perhaps most severe test: to convert the final informal text to a draft convention and move it through formal debate and formal procedures to final adoption.

To be sure, the eighth session had its diversions. They might usefully be described before the detailed discussion of its substantive work.

\section{Deep Seabed Mining Legislation}

On the first day in Geneva and the last day in New York, the chairman of the Group of 77 made a statement that challenged the legality of national legislation authorizing deep seabed mining and argued that its enactment would violate the rule of good faith in negotiations and have an impact beyond the sphere of the conference on economic cooperation between developing and developed countries. The U.S. and other delegations reiterated that the contemplated legislation is consistent with existing international law and compatible with their commitment to the conclusion at the earliest possible time of a generally acceptable law of the sea convention. The arguments were substantially the same as those made during the seventh session. ${ }^{29}$

29 See Letter of April 25, 1979 prepared by Group of 77's Group of Legal Experts on Legislation, UN Doc. A/CONF.62/77; letter of Aug. 23, 1979 from Chairman of Group of 77, UN Doc. A/CONF.62/89; statement by the Vice Chairman of the U.S. delegation in response, UN Doc. A/CONF.62/93 (Oct. I, 1979); Oxman, The Sevinth Session, note 1 supra, at 30-38.

The Ministers of Foreign Affairs of the states members of the Group of $7 \%$, meeting in New York a month after the end of the 8th session, adopted on September 29 a resolution in which they:

\section{Declare that:}

(a) Any unilateral measures, legislation or agreement restricted to a limited number of States on sea-bed mining are unlawful and violate well-estiblished and imperative rules of international law;

(b) Such unilateral acts will not be recognized by the international community, and that, these acts, being unlawful, will entail international responsibility on the part of States who commit them, and an investor will not have legal security for his investments in activities in pursuance of such acts;

2. Urge all States to refrain from taking any unilateral action on seat-bed mining and appeals to them to bring the Third United Nations Conference on the Law of the Sea to a successful and early conclusion.

UN Docs. A/34/611 (Oct. 23, 1979), A/CONF.62/94 (Oct. 19, 1979).

On December 14, 1979, the U.S. Senate passed, and sent to the House of Representatives, a bill regarding deep seabed mining that would not, however, allow commercial recovery to commence before 1982. S. 493 (amendment No. 540), 96th Cong., 1st Sess. (1979), 125 CoNg. REc. S18554 (1979). In the 95th Congress, deep seabed 
A new element was the all but explicit attitude of some developing country leaders working the hardest to promote an accommodation on deep seabed mining issues that enactment of legislation at this time would be insensitive and could compromise their efforts. On the other hand, withdrawal of support for legislation could be misinterpreted as a lack of determination and could lead to serious miscalculations by others. Failure to deal properly with these competing considerations could cause disruption and delay.

\section{Exercise of Rights}

During the meeting in New York, there were news reports that the United States had instructed its forces to exercise the freedoms of the high seas beyond the 3-mile limit of the territorial sea currently recognized by the United States. ${ }^{3 "}$ Various foreign ministries requested immediate clarification, some issuing statements that such a policy was illegal and would violate their sovereignty in broader territorial seas.31 The Group of Coastal States at the conterence-largely dormant since the completion of negotiations on access to fisheries of the economic zone-met on several occasions to consider its response. ${ }^{32}$

mining legislation was passed by the House of Representatives but was not voted upon by the Senate before adjournment. H.R. 3350, 95th Cong., 2d Sess. (1978), 124 Cong. Rec. H734I, H7382 (1978).

$\therefore$ See N.Y. Times, Aug. 10, 1979, \$A, at 1. Responses of the U.S. Government to inquiries, based on guidance made available to the author, were generally as follows:

Early last year, the Administration undertook a review of international maritime claims and their possible effects on U.S. interests, particularly our interest in maintaining freedom of navigation and overflight. As you know, the United States recognizes only a three-mile territorial sea established from the coast within which any nation may exercise the right of innocent passage. Beyond three miles, we believe that all nations have the right to freely navigate or overfly these high seas. Our review concluded that U.S. interests, and the interests of the international community, are best served by maintaining our long-standing position. It was also recognized that a proliferation of maritime claims which purported to control navigation and overflight beyond three miles might endanger U.S. interests.

The study was concluded in March of this year. Acting on the conclusions of the study, the Departments of State and Defense were directed to insure that U.S. activities on the high seas were fully consistent with our long-standing policy. The Department of Defense was directed to insure that in normal operations they did not operate in a manner which might be construed as an acquiescence in a claim which we do not recognize. They were not, however, ordered to challenge, in an aggressive way, such clains.

The United States has indicated that it could accept a twelve-mile territorial sea, as part of a comprehensive agreement in the Law of the Sea Conference. Our recognition of such a limit is, however, contingent upon acceptance by other nations of the other provisions of the current LOS text relating to the freedoms of navigation and overflight, particularly transit through straits.

"1 See Declarations of Aug. 18, 1979 by the Foreign Ministers of Colombia, Ecuador, Chile and Peru, UN Doc. A/CONF.62/85 (Aug. 22, 1979).

$\therefore$ Chaired by Mexico, the Group of Coastal States includes most of the delegations of major coastal states except, in general, those that are major maritime powers or members of the Group of Landlocked and Geographically Disadvantaged States. As with similar groups, the criteria for membership are flexible, participation in meetings varies, and no attempt is made to discipline members. 
During the last week of the session, the Group of Coastal States declared, in part:

The Group of Coastal States noted with surprise and concern recent media reports that the Government of the United States of America had "ordered its Navy and Air Force to undertake a policy of deliberately sending ships and planes into or over the disputed waters of nations that claim a territorial limit of more than three miles."

In the view of the Group of Coastal States such a policy, which in its essentials has been confirmed by officials of the United States Government, is highly regrettable and unacceptable being contrary to customary international law, whereby a great majority of States exercise full sovereignty in their territorial seas up to a limit of 12 nautical miles, subject to the right of innocent passage. That policy is also inconsistent with the prevailing understanding at the United Nations Conference on the Law of the Sea which has recognized the validity of such a practice.

The Group has taken note of the clarification which was later made by officials of the United States Government to the effect: that there has been no order to challenge in an aggressive way the claims of other nations. However, the Group of Coastal States consider: the statement that the regime of high seas commences beyond three miles is clearly an anachronism.

The Group reaffirms its determination to continue working towards the early adoption of a generally acceptable comprehensive Convention on the Law of the Sea and, in the meantime, expresses it:s hope that every State will refrain from undertaking any actions that may adversely affect its relations with other States or the success of the conference. ${ }^{33}$

The United States made the following response:

It is both surprising and distressing that distorted press reports should have caused such a stir at the Law of the Sea Conference, where the views of the United States with respect to navigation and overflight have long been well known to all participants. Press reports notwithstanding, those views have not changed. Activities in the oceans by the United States are fully in keeping with its long-standing policy and with international law, which recognizes that rights which are not consistently maintained will ultimately be lost.

At the same time, it remains the firm position of the United States that a comprehensive Law of the Sea Treaty offers by far the best, and perhaps the last, opportunity to establish a universally agreed and conflict-free regime governing all uses of the world's oceans and their resources. We have indicated that, as part of such an agreement, we could accept a 12-mile territorial sea coupled with transit passage of straits used for international navigation, all within the context of the overall package deal. In this regard, we note that the Group of Coastal States reaffirms its determination to continue working towards the early adoption of a generally accepted comprehensive Convention on the Law of the Sea. at 3.

${ }^{33}$ UN Docs. A/CONF.62/90, A/CONF.62/SR.118 (provisional) (Aug. 30, 1979), 
Let us not be diverted from our shared goal by debate over the very differences in national regimes that compelled our governments to enter into negotiations in the first place. ${ }^{34}$

Statements criticizing the U.S. position were made by Angola, Argentina, Brazil, China, Colombia, Costa Rica, Ecuador, El Salvador, Peru, the Philippines, Romania, and Vietnam. ${ }^{35}$ The USSR said the Group of Coastal States was "justified in its anxiety, to which the Soviet delegation was sympathetic," but distinguished between 12-mile and 200-mile claims. ${ }^{36}$ The Soviet expression of regret that the United States had not refuted or denied the press reports: illustrates the extent to which political temptations may compromise substantive positions. Along with the other statements, it should be a warning to those who, in preference to a treaty, would rely on the major powers to make and enforce the law.

\section{Deep Seabed Mining}

One of the procedural innovations at the eighth session was the attempt to form a small working group to negotiate on various outstanding deep seabed mining matters. As has so often happened, what was supposed to be a "small" group of 21, composed of ten developing countries, ten industrialized states, and China, was soon expanded to include alternates and attracted large numbers of observers. Accordingly, by the time of the New York meeting, the Working Group of 21 (WG21) had evolved into a general coordinating mechanism in which the chairman of the First Committee was associated with the chairmen of Negotiating Groups $I$ and 2, and which also included the Group of Legal Experts on Settlement of (seabed) Disputes. In addition, having successfully completed his work as chairman of Negotiating Group 4, Ambassador Nandan of Fiji was requested to chair a group of consumers and land-based producers working on the question of production limitations.

It may be helpful to view many of the new texts on deep seabed mining as dealing with three types of problems:

(1) the need for considerable specificity in order to allay fears that the Seabed Authority, intentionally or otherwise, may use its discretion in ways that are discriminatory, that discourage mining by states or their nationals (or for that matter by the Enterprise), or that otherwise prejudice consumer interests (or land-based producer interests);

(2) the need to ensure that specific treaty provisions establish requirements that do not discourage seabed mining (or mining on land) and are accordingly based on reasonable projections of alternative economic possibilities; and

(3) the need to ensure that the powers of the Seabed Authority are exercised in a manner that reflects the desires not only of the majority but of the major economic interests at stake, particularly those of consumers, seabed producers, and land-based producers.

.4 UN Docs. A/CONF.62/92 (Oct. 1, 1979), A/CONF.62/SR.118 (provisional) (Aug. 30,1979 ), at 4 .

$\therefore$ UN Doc. A/CONF.62/SR.118 (provisional) (Aug. 30, 1979), at 5-8.

3. Id. at 6-7.

3T Ibid. 


\section{Mining Conditions}

To deal with the first problem, both the procedural and substantive requirements for obtaining a mining contract and operating under it must be specified precisely or within precise limits, or in some cases on the basis of reasonably precise criteria. One aspect of the need for precision is perhaps best understood by noting that if the relevant requirement is a prerequisite to mining, voting power alone cannot solve the problem. Major consumers and seabed producers can hope to have no greater assured voting power in the Authority than the reasonable prospect of preventing adverse decisions. They will be unable to impose positive decisions. The solution to the risk of inaction or deadlock is to establish the precise conditions for mining in advance: in the treaty and in the initial rules and regulations to be drafted by the preparatory commission.

The very nature of the problem of specificity made necessary a painstaking review of every provision of part XI and Annexes II and III. It accounts for most of the changes made in the ICNT/Rev. 1 and proposed in the report of the Working Group of $21 . .^{38}$

Those changes would be capped by the text suggested for Article 6, paragraph 3 of Annex II in the WG21 report. Under this provision, proposed plans of work of prospective miners are dealt with in the order in which they are received, and are subject to inquiry as to their compliance with terms of the convention and the rules, regulations, and procedures of the Authority. As soon as the inquiry is completed, "the Authority shall approve such plans of work, provided that they conform to the uniform and nondiscriminatory requirements established by the rules, regulations and procedures of the Authority," subject only to itemized exceptions. This provision applies to all organs of the Authority, including the Council. The itemized exceptions relate to specific limitations in the convention: namely, when the proposed area is included in a previously submitted plan of work, when the proposed area has been disapproved for exploitation on the grounds of serious harm to a unique environment, when selection among different applicants will be necessary because approval of all plans of work submitted during the particular period would exceed the production limitation, or when the proposed plan of work has been submitted or sponsored by a state that would thereby exceed the specified antimonopoly limits. While factual evaluation may be necessary to ascertain compliance with the specified requirements, the act of approving a plan of work is not discretionary.

The need for specificity also accounts in part for the second problem enumerated above. To the extent that quantitative standards and limitations are made specific, there must be reasonable assurance that they are consistent with alternative economic projections of reasonable probability. These requirements explain the prodigious detail of the texts on financial obligations of miners and the complexity of the interim production limitation. Preparation of these provisions poses a substantial, if not unique,

38 Note 3 supra. 
TABLE I

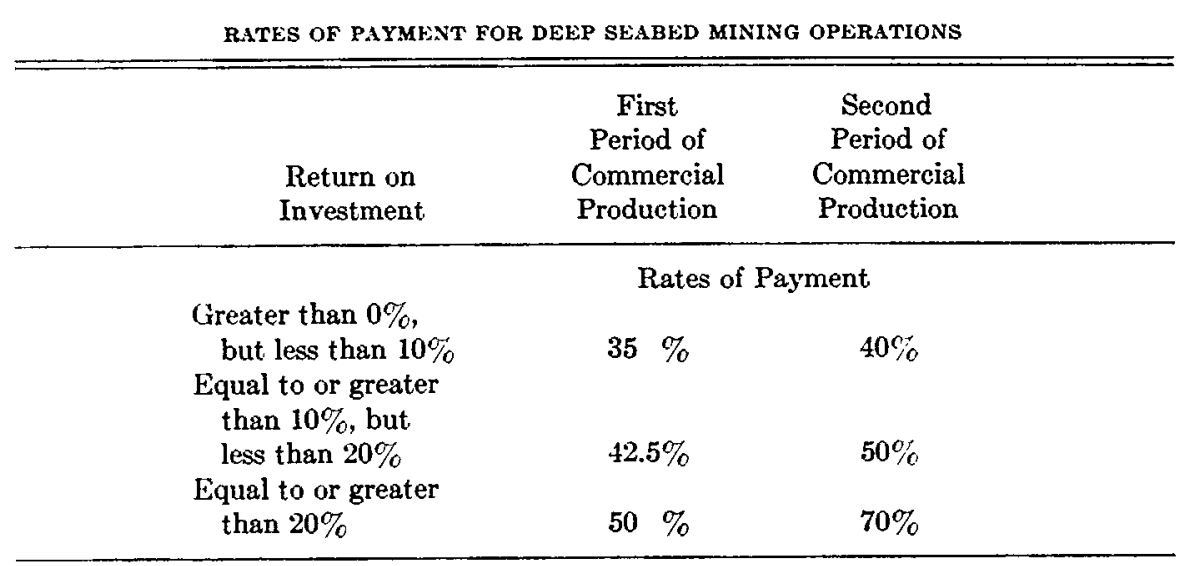

challenge to unite the disciplines of diplomacy, law, and economics in a group expert enough, small enough, but representative enough to negotiate results that can survive scrutiny by the conference.

\section{Financial Arrangements}

The texts contained in the WG21 report ${ }^{39}$ would permit a contractor to choose a mixed system under which he would make both payments proportional to production ${ }^{40}$ and payments proportional to profits, at rates adjusted to reflect alternative hypotheses of low, average, and high profitability. Relying generally on the ratio of the miner's development costs in the mining sector to his total development costs, the texts attribute to deep seabed operations a minimum of 25 percent of the net proceeds of a fully integrated three-metal project (nickel, copper, and cobalt). They establish two rates of payment for each incremental part of the attributable net proceeds, as shown in table I.

The second period begins when the contractor recovers his total development costs as "cash surplus," including interest at 10 percent per annum on that portion of his development costs not recovered by his cash surplus.

Thus, the Authority would share very handsomely in the proceeds of a highly efficient and profitable operation-a factor that should help alleviate concerns of both developing and industrialized countries. Estimated payments from a mine site over 20 years range from $\$ 258$ million to $\$ 1,964$ million." While many variables are involved, the differences in practice may still be substantial enough to persuade developing countries in the Authority

3. WG2I report, note 3 supra, App. A, text of Ann. II, Art. 12.

s" The production charge would be $2 \%$ per annum, but would rise to $4 \%$ in any year in the second period of commercial production in which the return on investment is at least $15 \%$. The contractor would pay either the production charge or an annual fixed tee of $\$ 1$ million, whichever is greater.

41 WG21 report, note 3 supra, at 22 (added by UN Doc. A/CONF.62/C.1/L.26/Corr.1 (Aug. 22, 1979)). 
of the desirability of promoting the efficiency of seabed miners and avoiding regulations that discourage or restrain efficiency. Even if they are only partly persuaded, this could be the incentive for a more general interest in promoting economic efficiency by representatives of developing countries whose interests as consumers alone have proved to be insufficient incentive. The economic importance of such an evolution, of course, transcends deep seabed mining alone. Other things being equal, an experiment on a relatively modest scale that gives developing countries a direct financial stake in the profits derived from efficiency may have much to commend it at this time.

These are, however, considerations for the future. The reluctance of developing countries to accept lower financial obligations for miners, particularly in early or less profitable years, was related directly to the developing countries' desire to ensure that the Enterprise has enough money to commence mining quickly, either on its own or as a substantial joint venture partner. The more apparent the desires of industrial states to avoid a heavy "front-end load" on the financial obligations of miners and to insulate their right to obtain a contract from vague requirements of support for the Enterprise, the greater the concerns expressed by developing countries about the financial capacity of the Enterprise to go inito business.

Thus, the text proposed in the WG21 report ${ }^{42}$ would require that the Enterprise be assured of the funds necessary to explore and exploit one mine site and to transport, process, and market the metals recovered from that site. The amount in question would be determined by the Assembly on the recommendation of the Council, which, in turn, would be advised by the Governing Board of the Enterprise. ${ }^{43}$ States parties would be required to make available to the Enterprise one-half of the sum in the form of long-term, interest-free loans. The other half would be borrowed by the Enterprise on commercial markets, but the loans would be guaranteed by the states parties. While repayment of the commercial loans would take priority over repayment of the government loans, the text does not spell out details of the latter, merely specifying that a schedule of repayment shall be adopted by the Assembly on the recommendation of the Governing Board of the Enterprise.

Current estimates of the cost of developing a mine site vary from $\$ 750$ million to over $\$ 1,100$ million. The obligations of states parties would be apportioned among them in accordance with the normal United Nations scale of assessments. For example, under the current level of assessments the United States would be expected to provide 25 percent of the government loans and to guarantee 25 percent of the commercial loans. Since the main creditor states will be a small group, it is appropriate that a balanced organ of the Authority responsive to their interests, as well as to the interests of the debtor, deal with such matters. The Council of the Au-

42 WG21 report, note 3 supra, App. A, amendments to Ann. III, Art. 10.

43 Under ICNT/Rev.1, Annex III, Article 5, the Governing Board of the Enterprise would consist of "15 qualified members" elected by the Assembly of the Authority "based on the principle of equitable geographical representation." 
thority might satisty this need, while the Assembly and the Governing Board of the Enterprise would not. Accordingly, further work on these problems can be anticipated.

\section{The Assembly and the Council}

The third problem, namely, the need to ensure protection for the major economic interests at stake, was the subject of particularly intensive consideration in New York after the issuance of the ICNT/Rev.1. The negotiations have generally proceeded on the assumption that such protection would be afforded in a Council of limited size whose composition and voting patterns were designed to balance and reflect the various interests. This approach, however, raises questions about the allocation of powers and functions to other organs of the Authority where such protection is not afforded, in particular the Assembly.

The texts in the WG21 report reflect substantial progress on these questions. They avoid any implication of broad implied powers in any organ by specifying that the powers and functions of the Authority are those "expressly conferred upon it by" the convention and only include "such incidental powers, consistent with the provisions of this Convention, as are implicit in and necessary for the performance of these powers and functions with respect to activities in the Area." 44 In addition, a new provision requires each principal organ of the Authority, in exercising its powers and functions, to "avoid taking any action which may derogate from or impede the exercise of specific powers and functions conferred upon another organ." - While the developing countries refused to eliminate the term "supreme organ," it was possible to elaborate on its use by changing the provision in question to read, the "Assembly, as the sole organ of the Authority consisting of all the members, shall be considered the supreme organ of the Authority to which the other principal organs shall be accountable as specifically provided in this Part." 45

In a similar vein, the text proposed by the chairman of the Group of Legal Experts on settlement of disputes would provide for selection of the 11 members of the Seabed Disputes Chamber by the Law of the Sea Tribunal itself, rather than by the Assembly of the Seabed Authority. The Assembly could make recommendations of a general character with regard to criteria for selection, it being understood that these would be guidelines only and would not relate to specific membership. ${ }^{.7}$

One problem regarding the relationship between the Council and the Assembly is that the confusion in the provisions concerning the adoption of rules, regulations, and procedures has not been eliminated. There are several different provisions on this matter that could usefully be united. ${ }^{48}$

i4 WG2l report, note 3 supra, App. A, Art. 157.

1. Id., Art. 158 .

45. Id., Art. 160.

4. Id., amendment to Ann. V, Art. 36.

1hICNT/Rev.1, Art. 160(2)(f), (j), and (n) and Art. 162(2)(n) and (p). 
The most precise of them (Article 160, paragraph 2(n) and Article 162, paragraph $2(n)$, refer to each other and would provide a sound basis for consolidation. ${ }^{49}$

Discussion of the voting question centered on a so-called "iwo-tier" approach to substantive issues in the Council. With respect to specified issues for which the special interests at stake need relatively less protection, a decision would require a two-thirds majority of those present and voting, including an absolute majority of the members of the Council. With respect to all other substantive matters, the requisite vote would be a twothirds majority of those present and voting, but only if a fixed number of negative votes were not cast. Although this proposal is contained in the WG21 report, ${ }^{50}$ the United States and other Western delegations had already indicated that they could not support it in the absence of a satisfactory blocking number. They could accept the number 5 for this purpose, while developing countries' "compromise" suggestions generally ranged from 7 to 9 . Meanwhile, the Soviet delegation continued to support the voting approach contained in the ICNT, ignoring the fact that it had already been completely rejected as a basis for agreement. Therefore, as a practical matter, a basis for consensus on the key problem of voting has thus far eluded the conference.

In connection with agreement on a satisfactory blocking number, the voting proposal in WG21 would eliminate the provision in the ICNT/Rev.1 that a plan of work would be deemed to be approved by the Council unless disapproved within 60 days of its submission by the Technical Commission.01 The new text ${ }^{3: 2}$ would require the Council to act on a plan of work within 60 days of its submission. The plan would be deemed to be approved unless a proposal for its approval or disapproval had been voted upon within that 60-day period. Developing countries, in pressing for this change, argued that the ICNT rule could result in the approval of a plan of work even if the commission's recommendation and a majority vote of the Council were opposed to it. The proposed change in the text, however, goes much further than is necessary to deal with this point, particularly since the approval of a plan of work is not a discretionary function. ${ }^{53}$

${ }^{49}$ Given the technical and legally binding character of the rules, re,zulations, and procedures, the author would note his long-held preference for their subrnission by the Council to governments, coupled with a time limit for disapproval by a specified number of parties, as in the ICAO and 1973 IMCO Conventions, rather than (or perhaps after) submission to the Assembly. An approach such as that taken in the 1973 Marine Pollution Convention, which provides special protection for interested states in the entry into force procedure for technical regulatory changes, could be a basis for helpful protections to supplement those provided by the composition and voting rules of the Council. Convention on International Civil Aviation, 1944, 61 Stat. 1180, TIAS No. 1591, 3 Bevans 944, 15 UNTS 295; International Convention for the Prevention of Pollution from Ships, 1973, IMCO Doc. MP/CONF.WP.35, reprinted in 12 ILM 1319 (1973).

so WG2I report, note 3 supra, App. A, amendments to Art. 161.

${ }^{51}$ Art. 162(2)(j).

52 WG2I report, note 3 supra, App. A, amendment to Árt. $162(2)$ (j).

53 Of course, the substantive provisions regarding approval of contrazts that have already been discussed, including Annex II, Article 6, are also relevant to this problem, 
The question of voting is also related to the question of composition of the Council. A variety of proposals on the matter will have to be considered at the next session, including one by the United States that the overall membership of the Council represent at least 50 percent of world production and 50 percent of world consumption of the categories of minerals that are produced from the deep seabeds. ${ }^{54}$

\section{Settlement of Disputes}

The work done by the Group of Legal Experts on Settlement of Disputes regarding the deep seabeds is reflected both in the ICNT/Rev.1 and in the WG21 report. Among the interesting new provisions are amendments to Article 168 that provide for redress, including the possibility of dismissal, against staff members of the Authority who disclose any proprietary data or confidential information of commercial value. The Authority is required, at the request of an affected party, to submit the complaint against the staff member concerned "to an appropriate tribunal," which presumably could include a special administrative tribunal established by the Authority. The Secretary-General of the Authority is required to dismiss the staff member concerned if the tribunal so recommends. ${ }^{55}$

The Group of Legal Experts devoted a great deal of time to the question of jurisdiction of the Seabed Disputes Chamber. The ICNT/Rev.l reflects the view that a contractor may elect commercial arbitration rather than the Seabed Disputes Chamber for disputes arising under a contract, but the provision requires clarification. ${ }^{56}$

as are important dispute settlement questions such as the nature of the tribunal and the ucope of review.

* While the effect of an existing proposal in Articles 161(1)(a) and (b) of the ICNT/Rev.l that amounts to a guaranteed seat for the Soviet Union and a Soviet ally among the largest seabed mining countries and consumers is mainly psychological, and by no means unflattering to Western technology, the provision is politically unpopular and might become an issue.

$\therefore$ While the problem of protecting the confidentiality of commercial information is dealt with in the same provision as problems of misconduct generally, its purpose is at least as much the direct protection of state and private property as protection of the Authority or its internal administration. Dismissal may be an inadequate deterrent, for example, when the employee is planning to leave or has left. The provision does not deal with the allocation of criminal or civil jurisdiction among the states concerned. Short of universal jurisdiction, jurisdiction to try or hear a case against the staff member for unlawful disclosure might exist in the state of his nationality, in the state affected by the violation, or in the state in which the violation occurred. This jurisdictional approach is consistent with that of the ICNT/Rev.I to questions such as pirate broadcasting and pollution. See Arts. 109, 142, 216, 217, 218, 220, and 221. A violation of the confidentiality requirements of the convention by a staff member might not be an act performed in the exercise of his functions for the purpose of immunity from legal process under Article 181. Even if it were such an act, the substance of the new provision in the WG21 report would seem to preclude a claim of immunity or require its waiver in appropriate cases. Moreover, the WG21 report's amendment to Annex II, Article 21 makes clear that the Authority would be liable for violation of the confidentiality requirement by the Secretary-General and the staff.

in ICNT/Rev.1, Art. 188. This clarification might perhaps include harmonization with the special provision on arbitration regarding financial terms of a contract found 
The question whether disputes over deep seabed mining involving, or at least between, states parties should be subject to the mandatory jurisdiction of the Seabed Disputes Chamber, or to the same choice of procedures (including arbitration) enjoyed with respect to other disputes under the convention, ${ }^{57}$ is approaching resolution on the basis of permitting the formation of a special chamber of the Law of the Sea Tribunal or an ad hoc chamber of the Seabed Disputes Chamber. ${ }^{58}$

One of the most important issues relating to the proposed Seabed Authority concerns fears that its organs may exceed or misuse their powers in violation of the convention. This issue poses classic questions of judicial review dealt with in the constitutional and administrative law of many countries. There were few problems with the principle of judicial review of administrative acts, as such review is common in municipal law. The difficulty arose over the exercise of discretionary powers to adopt rules, regulations, and procedures regarding activities in the Area, the essence of the regulatory or quasi-legislative functions of the Authority. These decisions require the concurrence of both the Council and the Assembly.

The solution proposed is to prohibit the tribunal from substituting its own discretion for that of the Authority, and from making any general pronouncement on the validity of a rule, regulation, or procedure or on its conformity with the convention. On the other hand, it can determine that the application of a rule, regulation, or procedure in a particular case would conflict with the obligations of one of the parties (e.g., the Authority) under the convention or a contract, and it can consider claims concerning lack of competence or misuse of power, as well as claims for damages or other remedies for failure to comply with the convention or a contractual obligation. ${ }^{59}$

Article 295 repeats the traditional rule in the Statute of the International Court of Justice that a decision has no binding force except between the

in Annex II, Article 12, paragraph 15. It should also be noted that Annex II, Article 5, paragraph 2 contains elaborate conciliation and arbitration provisions regarding the miner's contractual undertaking to make technology available to the Enterprise "on fair and reasonable commercial terms and conditions." The specificity of the contract, coupled with its required guarantee of "security of tenure" (Art. 15B, para. 6 and Ann. II, Art. 15), supply the legal foundation for arbitral protection of contractual expectations against "public law" intrusions. See arbitral award between Texaco Overseas Petroleum Co./California Asiatic Oil Co. and Libya, reprinted in 17 ILM 3 (1978) and discussed generally infra at p. 134.

${ }^{57} \mathrm{See}$ ICNT/Rev.1, Art. 287.

58 WG21 report, note 3 supra, App. A, Art. 188. The underlying concept is that the selection by the parties of 3 judges from a larger number approximates, or at least accommodates, the views of those favoring arbitration. Submission of the dispute to the special chamber of the Law of the Sea Tribunal would require the assent of both parties, while submission to the ad hoc chamber of the Seabed Disputes Chamber would be mandatory if any party requests it. Only the former could include nationals of the parties. Compare ICNT/Rev.I, Ann. V, Arts. 15 and 17 with the proposed Ann. V, Art. 36 bis in the WG21 report, App. A.

so ICNT/Rev.1, Art. 190. 
parties and in respect to that particular dispute. ${ }^{60}$ In this light, the distinction between jurisdiction to declare a regulation invalid and jurisdiction to declare its application in that case unlawful might withstand scrutiny, it Article 295 applies to decisions against the Authority at all. What must be noted is that under Article 152, the Authority is required to avoid discrimination in the exercise of its powers and functions.

A general substantive prohibition on discrimination among members would seem to be implicit in the law governing regulatory actions of international organizations and is explicit in the proposed law of the sea convention. When the Authority loses a case, it must adjust its subsequent treatment of similarly situated entities in order to avoid discrimination. Moreover, a court will not wish to render inconsistent decisions if it thereby puts itself in the position of requiring the Authority either to violate its nondiscrimination obligation or to readjust its regulations frequently. ${ }^{61}$

\section{The Continental Shelf}

At the end of the seventh session, two competing formulas for defining the outer limit of the continental shelf where it extends beyond 200 miles from the coast were under consideration. ${ }^{62}$ The so-called Irish formula provided for alternative criteria of distance from the foot of the continental slope or thickness of sediment in relation to the distance from the foot of the continental slope. ${ }^{8 s}$ The Soviet formula provided for a fixed distance from shore of 300 miles from the coast (baseline) as the maximum permissible limit for the continental margin where it extends beyond 200 miles. $^{64}$ In addition, at least some Arab countries maintained a formal reservation regarding any coastal state jurisdiction over the continental shelf beyond 200 miles. $^{65}$

\section{The Outer Limit}

The idea of combining the Irish and Soviet formulas occurred naturally enough. The basis for any such combination would be the following points:

ov Art. 59, Statute of the ICJ.

"ir This would be true whether or not res judicata and collateral estoppel are technically available. The technical point would be one of offensive use of collateral estoppel by a stranger to the earlier case against the party defeated in the earlier case. This practice recently received the qualified approval of the Supreme Court of the United States, despite the absence of "mutuality" (i.e., the party asserting collateral estoppel would not have been bound or estopped by the earlier judgment). Parklane Hosiery Co. v. Shore, 99 S.Ct. 645 (1979). As to the offensive use of collateral estoppel on a question of law, it might be observed that the jurisprudence of common law jurisdictions would tend to be colored by the doctrine of stare decisis, while the jurisprudence of many administrative courts in civil law jurisdictions (among others) in analogous situations would tend to be colored by their power to address questions of validity of regulations directly.

in 2 These are discussed by the author in 73 AJIL (1979) at pp. 19-22.

"Conf. Doc. NG6/1 (1978), reproduced in part in 73 AJIL 19 n.59.

is C.2/Informal Meeting/14 (1978), reproduced in part in 73 AJIL 20 n.61.

s: Conf. Doc. NG6/2 (1978). 
(1) The continental shelf extends to a defined outer edge of the continental margin or, irrespective of the geological nature of the seabed, to 200 miles from the coast (baseline).

(2) The continental margin is the natural prolongation of the land territory of the coastal state; it consists of the seabed and subsoil of the shelf, the slope, and the rise, and does not include the deep ocean floor or its subsoil.

(3) The Irish formula is a reasonable means for avoiding a "last grain of sand" misinterpretation of what is meant by the continental rise. It defines the outer edge of the continental margin by joining fixed points where the thickness of sedimentary rock is at least 1 percent of the shortest distance from such points to the foot of the continental slope or, alternatively, by joining fixed points that are not more than 60 miles from the foot of the continental slope.

(4) Notwithstanding the criteria of the Irish formula, there would be a maximum limit for the continental shelf applicable: only where the outer edge of the continental margin, as determined under the Irish formula, would otherwise extend beyond that limit.

The problem in dealing with the last point is that any cut-off expressed solely in terms of distance from the shore would have to be considerably greater than the 300 miles originally proposed by the Soviet Union in order to include certain areas important to some broad-margin states. Accordingly, the idea emerged of alternative criteria for the cut-off, cone expressed in terms of distance from the coast, and the other expressed in terms of distance from a readily identifiable seabed feature, in this case a specified isobath (depth contour). ${ }^{68}$

On the basis of broad negotiations along these lines, the chairman of the Second Committee and Negotiating Group 6 proposed a text that became Article 76 of the ICNT/Rev.I. For determining the cut-off, the chairman selected alternative criteria of 350 nautical miles from the coast (baseline) or 100 nautical miles from the 2,500-meter isobath, whichever is further seaward. Thus, the outer limit of the continental shelf (the area of the seabed and subsoil over which the coastal state exercises sovereign rights for the purpose of exploration and exploitation of natural resources) is the outer edge of the continental margin as defined under the Irish formula, except that:

(1) the continental shelf extends up to a distance of 200 nautical miles from the coast (baseline), even if the outer edge of the continental margin is at a lesser distance from the coast; and

(2) the fixed points defining the outer limit of the continental shelf may not exceed 350 nautical miles from the coast (baseline) or 100 nautical miles from the 2,500-meter isobath, whichever is further seaward.

${ }^{66}$ So stylized was the relationship between the opposing sides that for a considerable period, to symbolize its emergence from the center of the table rather than from any delegation, and perhaps to suggest a customary affection for tea among the original chefs, the proposal was called the "biscuit." 


\section{Ridges}

The provision that the continental margin "does not include the deep ocean floor or the subsoil thereof" contains a footnote recording a general understanding that a mutually acceptable formulation will be drawn up "on the question of underwater oceanic ridges." ${ }^{67}$ This wording correctly suggests that ridges that partake of the same qualities as the deep ocean floor or the subsoil thereof are not part of the continental margin, a conclusion that would seem apparent from the chairman's use of "underwater oceanic ridges" 88 since the word "oceanic" in the context of this phrase cannot be construed simply to mean "underwater."

The Irish formula is a means for establishing the "outer edge" of the continental margin. The continental margin remains the seabed and subsoil of the shelf, the slope, and the rise. By no stretch of the imagination can oceanic ridges such as the Mid-Atlantic Ridge properly be regarded as falling within this definition of the continental margin, nor can the sides of these great mountain chains be regarded as the foot of the continental slope for purposes of applying the Irish formula. The fact that a 2,500-meter isobath may surround a ridge is irrelevant. There is no basis for any other conclusion in the conference records, the informal debates, the intent of the lawyers and geologists working on the problem in the so-called Margineers Group, or the Secretariat study and maps illustrating various formulas for the definition of the continental shelf. ${ }^{69}$

The complication that arises because portions of the continental rise overlie the deep ocean floor should be resolved in the same way, whether the ocean floor is regular or irregular at that point. The statement, already contained in the text, that the continental margin "does not include the deep ocean floor" is properly construed to be consistent with the inclusion within the continental margin of those portions of the continental rise that overlie oceanic crust (and satisfy the criteria of the Irish formula); it would not seem logically necessary to do more in the text than clarify that this exclusion of the deep ocean floor from the definition of the continental margin applies, with the same effect, to the ridges of the deep ocean floor. ${ }^{70}$

67 ICNT/Rev.1, Art. 76, para. 3 and note 1.

6x Emphasis added.

${ }^{69}$ UN Doc. A/CONF.62/C.2/L.98 and Adds. 1 \& 2; R. Platzöder, note 3 supra, 3 GeNFER SEssion 1978, at 871 (Add. 1 maps not reproduced).

20 Objections to this approach by some broad-margin states seem to contradict the underlying interpretation of the article as a whole. It may be desirable, but it should be unnecessary to insist on, the introduction of a term such as "oceanic crust" for the first time and solely in connection with ridges. Conversely, insistence on exclusion of such a term is difficult to understand. Language similar to that used by the chairman of the committee in his footnote might be suitable. Nevertheless, legal and geological experts were drawn into complex discussions and drafting exercises about ridges of continental formation, plateaux, oceanic crust, and so on. See Report of Negotiating Group 6 , note 3 supra. To this observer, at times it seemed a final, sentimental replay of discussions regarding the nature of the continental margin that dominated earlier stages of the conference. 
The 2500-meter isobath may not be a particularly stringent limitation in areas where the seabed is highly irregular. To avoid unreasonable claims, the proposed Commission on the Limits of the Continental Shelf it should give careful scrutiny to the delimitation charts submitted by the coastal state for such areas. ${ }^{72}$

In this connection, it could be important to correct paragraph 7 of Article 76 along the lines suggested by Singapore and other delegations. ${ }^{73}$ The current text reads, "The limits of the [continental] shelf established by a coastal State taking into account these recommendations [of the Commission] shall be final and binding." it That sentence cannot conceivably mean what it seems to say, namely, that the coastal state can establish final limits binding on the rest of the world simply by "taking into account," but possibly in significant respects rejecting, the Commission's recommendations. It is reasonable to suggest that if the coastal state chooses to implement the Commission's recommendations, the limit should be final and binding. In other cases, there should be a procedure for dealing with the matter.

\section{Sri Lanka Proposal}

The chairman of the Second Committee and Negotiating Group 6 stated in another footnote that there was widespread sympathy for Sri Lanka because of the difficulty of applying the Irish formula to the geological and geomorphological conditions off its coast. Sri Lanka points out that the foot of the continental slope and the 2,500-meter isobath are very close to its coast, while there is an exceedingly broad continental rise that extends many hundreds of miles from the coast. Sri Lanka argues that this rise qualifies under the general principle that the continental margin consists of the shelf, the slope, and the rise but is excluded by the more detailed rules for defining the outer limit of the continental shelf and continental margin. Notwithstanding the genuine sympathy for Sri Lanka, there is opposition to relaxing the requirements of Article 76, particularly if relaxation would have the effect of broadening the limits of the continental shelf off other states as well. ${ }^{T 5}$

${ }^{71}$ The text of the informal Canadian paper on the organization and functions of the commission appears in 73 AJIL $20 \mathrm{n} .62$. Informal consultations were held on the basis of this paper; agreement seems imminent.

72 It might be noted that the "rule of thumb" regarding the location of the foot of the continental slope (the point of maximum change in gradient at its base) applies only "in the absence of evidence to the contrary." More important, as noted before, the Irish formula deals with the location of the outer edge of the continental margin. It provides no justification for placing that outer edge in an area that is beyond the continental margin itself, that is, beyond the shelf, slope, and rise. These and other factors would presumably be considered by the commission in reviewing the submissions of the coastal state.

${ }^{73}$ See Report of Negotiating Group 6, note 3 supra, item (d).

74 Bracketed words added.

${ }^{75}$ The conference has become increasingly sensitive to permitting generalized extensions of the continental shelf to vast distances from the coast. It seems (with 


\section{Revenue Sharing}

The general approach of the ICNT to the sharing by the coastal state of revenues from mineral exploitation of the continental shelf beyond 200 miles was retained. ${ }^{7 s}$ While the revision of the ICNT maintains the 1 percent annual increments in payment to commence after 5 years, it increases the maximum rate of payment by the coastal state to 7 percent of the value of production reached in the 12th year of commercial production at the site, rather than the previous 5 percent reached in the 10 th $^{7}{ }^{7 \pi}$ Proposals were made to shift this formula to a more complex one based on net profits, but they had little support.

A related question was raised about the exclusion of any developing country from the revenue-sharing obligation for a mineral resource produced from its continental shelf when the country is a net importer of that resource. $^{\text {is }}$ Since it is likely, particularly in the early years, that only very large potential oil and gas fields will be developed in most areas where the continental shelf extends beyond 200 miles from the coast, a coastal state capable of consuming all that oil and gas and still needing to import more may well be considerably more advanced than many other developing countries.

The U.S. delegation proposed alternative means of dealing with this question that would apply to all developing coastal states, not merely net importers. A developing coastal state would have two options. It could choose to remain in the system, making the payments required of it. In that case, in calculating its benefits, an adjustment would be made in order to produce an equitable result. Alternatively, the developing coastal state could opt out altogether for a fixed period of years. In that case, it would neither make payments nor receive benefits under the system. ${ }^{79}$

exceptions, of course) to feel occasional remorse about the extent of the limits already reached. In particular, proposals that would breach both cut-offs ( 350 nautical miles from the coast or 100 nautical miles seaward of the 2500 -meter isobath) seem to arouse concern.

${ }^{73}$ See Stevenson \& Oxman, The 1975 Geneva Session, note 1 supra, at p. 782 \& n.43; Oxman, The 1977 New York Session, note I supra, at pp. 80-81.

${ }^{72}$ ICNT/Rev.I, Art. 82, para. 2.

78 ICNT/Rev.1, Art. 82, para. 3.

79 Before leaving the seabeds, it might be noted that in case the conference is in need of additional complexity and controversy, it can find it in new excursions into the arcane interstices of the law of salvage. Two proposals have been made that seem reasonably likely, once their texts are carefully scrutinized, to drive museum directors, anthropologists, archeologists, collectors, shipowners, ship charterers, cargo owners, artists, and adventurers to distraction. Their description in the Report of the Second Committee, note 3 supra, at 73 , is repeated here without further comment:

Article 77

Informal suggestion by Cape Verde, Greece, Italy, Malta, Portugal, Tunisia and Yugoslavia (Doc. C.2/Informal Meeting/43/Rev.1) to add a new paragraph 5 giving the coastal State sovereign rights over any object of an archaeological and historical nature on or under its continental shelf for the purpose of research, salvaging, protection and proper presentation. The State or country of origin, or the State of historical and archaeological origin, would have preferential rights 


\section{Marine Scientific Research}

From a procedural standpoint, difficulties over the ICNT provisions on marine scientific research had their roots in the failure of the ICNT text to adhere to the provisions worked out earlier in the context of negotiations on the status of the economic zone. ${ }^{80}$ Although largely tactical, the hesitation of coastal states to agree to alter the ICNT provisions to conform to those previously negotiated aggravated the negative reaction of the scientific community to the text. As a result, after carefully z.nalyzing the various problems posed and reluctantly proceeding on the assumption that the overall structure agreed to in the context of the economic zone negotiations and largely reflected in the ICNT would have to be preserved in any agreement, the United States presented a series of technical amendments and adjustments. ${ }^{81}$

Constructive discussions were held by heads of delegation in Geneva on this matter. While these discussions led to a revision of the U.S. proposals, there was insufficient opportunity to ready them for incorporation into the revised Informal Composite Negotiating Text, in part because some of the same heads of delegation were preoccupied with the intense negotiations on the outer limit of the continental shelf.

The two issues were linked substantively. One of the proposed amendments eliminated the requirement that the coastal state consent to scientific research on the continental shelf where it extends beyond 200 miles from the coast. The relationship between these issues was expressly noted by the chairman of the Second Committee and Negotiating Group 6 in presenting the articles on the definition of the continental shelf, and it was stressed by the United States in its comments on those articles. The chairman of the Third Committee, with the support of numerous delegations, announced his intention to hold intensive negotiations on marine scientific research in New York.

The texts resulting from those negotiations are contained in the report of the chairman of the Third Committee submitted at the end of the New York meeting. ${ }^{82}$ While noting the need for additional work, the chairman stated his assessment that the texts "have a considerable degree of support as to provide a reasonable prospect for consensus." They "could serve as a basis for subsequent agreement leading to the revision of the ICNT."

over such objects in the case of sale or any other disposal, resulting in the removal of such objects out of the coastal State.

\section{Article 98}

Informal suggestion by Bulgaria, the Byelorussian Soviet Socialist Republic, Czechoslovakia, the German Democratic Republic, Hungary, Poland, the Ukrainian Soviet Socialist Republic and the Union of Soviet Socialist Republics (Doc. C.2) Informal Meeting/44) to add a paragraph 3 providing that, withoust prejudice to the provisions of the Convention and other universally recognized rules of international law, sunken ships and aircraft, as well as equipment and cargoes located on board them, may be salvaged only by the flag State or with its consent.

80 These negotiations were discussed by the author in 72 AJIL (1978), at pp. 75-78.

81 See 73 AJIL at pp. 27-30. 82 Note 3 supra. 
The basic structure of the marine scientific research regime for the economic zone and the continental shelf set forth in the ICNT/Rev.1 is as follows:

(1) such research "shall be conducted with the consent of the coastal state";

(2) coastal states "shall, in normal circumstances, grant their consent" for such research; and

(3) coastal states "may however in their discretion withhold their consent" if a project falls within one of several categories, the most important being if a project "is of direct significance for the exploration and exploitation of natural resources, whether living or nonliving." 83

Six months" advance submission to the coastal state of a "full description" of the project is required. ${ }^{84}$ The ICNT/Rev.I also requires the researching state to comply with a number of obligations, such as ensuring the right of the coastal state to participate or be represented in the project, submitting final results and an assessment of those results to the coastal state, and providing access for the coastal state to all data and samples. ${ }^{\text {s.s }}$

\section{Normal Circumstances}

The elaborate specification of circumstances in which the coastal state may in its discretion deny consent logically proceeds on the expectation that in other cases the coastal state will grant consent. Thus, the approach of the ICNT is different from the approach of the Convention on the Continental Shelf, which merely requires that the coastal state shall not "normally" withhold its consent. ${ }^{86}$ The use of the word "normally" was suggested at one point by the chairman of the Third Committee as pos-

${ }^{* 3}$ Art. 246. The other grounds for discretionary refusal of consent under paragraph 4 are:

(1) The project involves the use of explosives or the introduction of harmful substances into the marine environment.

(2) Information submitted to the coastal state regarding the nature and objectives of the project is "inaccurate." (This is the basic control over the bona fides of the project description.)

(3) The researching state has outstanding obligations to the coastal state from a prior research project. (The obligation is, of course, not "outstanding" for these purposes if by its nature it cannot be fulfilled until after completion of the research cruise [e.g., preparation of reports] and good faith efforts are being made for its timely fulfillment.)

(4) The project involves drilling into the continental shelf. (This simply repeats the requirement of consent for drilling in Article 81.)

(5) The project involves the construction, operation, or use of artificial islands, installations, and structures as referred to in Articles 60 and 80 . (This crossreferences the requirements for consent under those articles.)

84 ICNT/Rev. 1, Article 248 describes in detail the information to be included.

85 Id., Art. 249.

${ }^{*}$ Convention on the Continental Shelf, 1958, Art. 5, para. 8, 15 UST 471, TIAS No. 5578, 499 UNTS 311, reprinted in 52 AJIL 858 (1958). 
sibly facilitating compromise, but was rejected in the course of the negotiations. ${ }^{87}$

The United States and others argued that given the careful elaboration of the discretionary exceptions, the coastal state should be obliged to grant its consent in all other cases. But this conclusion was found inappropriate for situations in which substantial hostility or tension between them made it "impossible" and "unrealistic" to expect the coastal state to consent to the presence of a scientific research vessel of the researching state off its coast. Some alluded to situations in which the two governments not only do not maintain diplomatic relations but do not even accord each other recognition. Others alluded to situations of intermittent armed conflict between the two states. The key point is that the abnormal circumstances that would justify a denial of consent were intended to refer to circumstances between the coastal state and the researching state characterized by hostility or tension of such a serious nature as rationally to preclude the granting of consent. ${ }^{88}$

Essentially, the problem was not so much to define "normal circumstances" as to elaborate on its meaning. Thus, the chairman's text provides that "the absence of diplomatic relations between the coastal state and the researching state does not necessarily mean that normal circumstances do not exist between them for purposes of applying" the requirement that consent be granted in normal circumstances. ${ }^{89}$

\section{The Continental Shelf Beyond 200 Miles}

Application of the standard of "direct significance for the exploration and exploitation of natural resources" was the heart of the problem regarding marine scientific research on the continental shelf where it extends beyond 200 miles from the coast.

First, the language could be interpreted as affecting scientific research in the water column beyond the economic zone. The states with broad continental margins pointed out that this difficulty was merely one aspect of the general problem of the relationship between the rights of the coastal state over the continental shelf and high seas freedoms, which was being dealt with in the negotiations on the continental shelf in Negotiating Group 6. ${ }^{90}$ As a result, language was added by the chairman of the Second Committee in the revision of the ICNT continental shelf articles that provides, "The exercise of the rights of the coastal State over the continental shelf must not infringe, or result in any unjustifiable interference with navigation and other rights and freedoms of other States as provided for in this Convention." 91 While this language is derived from Article 5 of the Convention on the Continental Shelf,"2 the words "must not infringe" and the general reference to "rights and freedoms of other States" are new.

${ }^{87}$ See 72 AJIL (1978), at pp. 76-77. $\quad 88$ Ibid.

${ }^{89}$ Report of the Chairman of the Third Committee, note 3 supra, Annex, Art. 246 bis.

90 See 73 AJIL (1979), at p. 22.

92 Note 86 supra. 91 ICNT/Rev.1, Art. 78, para. 2. 
The second problem with the "direct significance" standard derives from the difficulty of ascertaining, with respect to the vast areas of the continental shelf beyond the exclusive economic zone, when marine scientific research on the shelf has direct significance in any practical sense for the exploration and exploitation of its natural resources. Differences on the matter were narrowed to a single issue: the exercise of discretion to withhold consent on resource grounds in areas beyond 200 miles. Requirements for notification, obligations, consent, and the discretion to withhold consent for one of the other specified reasons ${ }^{33}$ would not be changed. Differences were further narrowed when it was granted, on the one hand, that discretion to withhold consent on resource grounds would exist in areas where exploitation was occurring or about to occur, and, on the other hand, that it would not exist in areas where neither exploitation nor exploration was occurring or about to occur.

The issue was thus narrowed to exploration. The difficulty is that the term "exploration," when used in connection with the continental shelf, may mean a variety of things; it can include activities of a general nature covering very broad areas of the type referred to as "prospecting" in Annex II in connection with deep seabed mining. ${ }^{.4}$

Consideration was given to adopting the distinction between prospecting and exploration elaborated in Annex II ${ }^{y 5}$ for the purposes of applying discretion to withhold consent on resource grounds beyond 200 miles. However, some states noted that their mining systems would make this distinction difficult to apply. It was revealed in the course of examining these systems that exploratory drilling is a typical example of an activity associated with an advanced stage of intensive, localized exploration rather than a preliminary stage of general prospecting. ${ }^{96}$ This observation laid the foundation for the compromise: discretion of the coastal state to withhold its consent on resource grounds "shall be deferred and its consent shall be implied" with respect to projects undertaken "outside specific areas of the continental shelf beyond 200 miles ... which the coastal state has publicly designated as areas in which exploitation or exploratory operations, such as exploratory drilling are occurring or are about to occur." ${ }^{97}$

\section{Publication of Results}

The desire of states to restrict premature distribution of information about their natural resources obviously runs directly counter to the principle that the results of scientific research should be made available to all. The treatment of this issue in the ICNT/Rev.l was ambiguous and seemed to encourage restraints on publication of all research results. ${ }^{98}$ The redraft

${ }^{\mathrm{a}}$ See note 83 supra.

" ICNT/Rev.I, Annex II, Article 2 refers to the "broad areas in which prospecting is to take place."

$\because$ Compare Arts. 2 and 3 of Ann. II.

${ }^{96}$ This is generally the nature of the distinction made in Annex II and the national mining systems on which it is based.

:7 Report of the Chairman of the Third Committee, note 3 supra, Annex, Art. 246 bis.

9× See ICNT/Rev.1, Art. 249, paras. 1(e) and 2. 
makes clear that since the coastal state can in its discretion withhold consent for a project of direct significance for the exploration or exploitation of natural resources, it can require, as a condition for granting such consent, prior agreement on making the results internationally available..$^{00}$

\section{Settlement of Disputes}

Two similar provisions of the ICNT/Rev.1, Articles 264 and 296, paragraph 2, excluded from third-party adjudication or arbitration disputes arising out of the exercise by the coastal state of a right or discretion under Article 246 (the basic consent provision regarding the economic zone and the continental shelf) or a decision by the coastal state to terminate a research project under Article 253. Thus, a tribunal could not go beyond ascertaining the existence in that case of a right or discretion to withhold consent or a right to terminate a project.

The text in the chairman's report is designed to accommodate opponents of this exclusion by providing for compulsory conciliation of the question whether the coastal state is exercising these rights in a manner compatible with provisions of the convention, "provided that the conciliation commission shall not call in question the exercise of the discretion to withhold consent in accordance with article 246, paragraph 4." 100 This, of course, reflects the basic point that once it is established that the only issue relates to a decision of a coastal state to withhold consent in the exercise of the discretion conferred on it by the convention, there is no longer a substantive basis in the convention itself for review, since it specifies no criteria for the exercise of that discretion. On the other hand, tesmination of a research project is subject to such third-party review.

\section{Additional Clarifications}

Several additional clarifications are included in the report. The coastal state's right to suspend or terminate a project already under way on grounds of variance from the project description is conditional on its not having secured compliance within a reasonable time. ${ }^{101}$ The change attests to the fact that this power of the coastal state is considerably more onerous than the power to deny consent before a project begins. There is also an exhortation to facilitate access of marine scientific research vessels to harbors. ${ }^{102}$

Perhaps the most interesting addition is that in applying the scientific research provisions, and "without prejudice to the rights and duties of States" under the convention, a state "shall provide when appropriate other States with a reasonable opportunity to obtain from it, or with its co-operation, information necessary to prevent and control damage to the

\footnotetext{
${ }^{99}$ Report of the Chairman of the Third Committee, note 3 supra, Annex, Art. 249. Neither the ICNT nor the new text alters the obligations under sections 1 and 2 of part XIII, including Article 244.

100 Report of the Chairman of the Third Committee, note 3 supra, Annex, Art. 264.

101 Id., Art. 253. 102 Id., Art. 255.
} 
health and safety of persons and the environment." ${ }^{103}$ It is regrettably characteristic of the sense of international solidarity of some of those concerned with scientific research in this conference that an obligation to provide merely a "reasonable opportunity" to obtain "necessary" information already in existence, or by virtue of joint cooperation, and then without prejudice to any coastal state rights, should only exist "when appropriate." Even if these last words are not clarified, they should be understood in context as reflecting the general concern about good faith and harassment that dominated all the science negotiations, that is, as requiring the coastal state to respond positively to good faith requests whose importance is commensurate with the difficulties of supplying the information. The words were not intended to nullify the entire article or duties implied by other legal principles, such as those regarding protection of health and the environment, to say nothing of the friendly relations of states.

\section{Delimitation Between States with Opposite or Adjacent Coasts}

The function of the provisions on the exclusive economic zone and the continental shelf is to define the respective rights and duties of any coastal state and all other states as a class in the same area. This relationship is dealt with in considerable detail, constituting the essence of the so-called package deal in this regard.

The question of the substantive rules governing delimitation between states with opposite or adjacent coasts poses a different kind of issue. ${ }^{104}$ To the extent that the law of the sea allocates geographic jurisdiction to the coastal state, how do neighboring coastal states divide areas of geographic jurisdiction?

There is a community interest in ensuring that they do so peacefully. Moreover, important interests of states other than the coastal state depend for their protection upon the exercise of the rights or fulfillment of the duties of the coastal state. Protecting these interests could be difficult in practice in areas where there is a dispute over which coastal state has the right and responsibility to act.

The substance of this division, however, is of no concern to the class of other states. No matter which area is assigned to which coastal state, the rights and duties of both in relation to the international community as a whole will be the same. In any given delimitation dispute between two coastal states, some third state may believe its interests will best be served

103 Id., Art. 242.

1"* The relevant ICNT/Rev.I provisions, Article 74, paragraph I (economic zone) and Article 83, paragraph 1 (continental shelf), use the same language. Different language is used in ICNT/Rev.1, Article 15 regarding delimitation of the territorial sea: this provision, now agreed, is substantially the same as the provision in Article 12 of the Convention on the Territorial Sea and the Contiguous Zone, note 22 supra. While the ICNT retains the concept of the contiguous zone in Article 33, it does not contain a delimitation provision that mentions the contiguous zone. Compare Art. 24, Convention on the Territorial Sea and the Contiguous Zone. 
if a particular one of the two prevails, but this does not imply a substantive interest on the part of the class of other states in the nature of the delimitation.

The limits of coastal state jurisdiction specified by the convention with respect to the exclusive economic zone and the continental shelf ${ }^{105}$ define the maximum scope for competing coastal state claims. The basis for the exercise of coastal state jurisdiction is the geographic relationship between an offshore area and the coast. A comparative inquiry into the merits of various claims, therefore, is focused on the nature of the geographic relationship to the coastlines of the respective coastal states.

When examined rigorously, all of the major positions on delimitation between states with opposite or adjacent coasts proceed on the basis of these premises.

Those who emphasize equidistance in effect wish to ensure not only that delimitation is based upon the geographic relationship between the offshore area in question and the respective coastlines, but that the most significant geographic relationship is proximity. They nevertheless grant that the equidistance method may not be applicable, for example, where there are "special circumstances." 106

Those who emphasize equitable principles wish to see that all aspects of the geographic relationship between the area in question and the respective coastal states are weighed, including, but not limited to, proximity. The reference to equitable principles in the ICNT is understood to be a reference to the criteria elaborated by the International Court of Justice in the North Sea Continental Shelf cases. ${ }^{107}$ Those criterie. refer to the geographic relationship between the area in dispute and the respective coastal states. ${ }^{108}$

Needless to say, such nuances of emphasis bear little relationship to the practical matter of promoting agreement between the coastal states concerned. They are relevant, if at all, to formal adjudication or arbitration. It is reasonably clear, however, that the law of the sea convention will not generally require arbitration or adjudication of delimitation disputes. Moreover, the jurisprudence, scholarly writings, and state practice on offshore delimitation are growing rapidly. It is unlikely that a judge or arbitrator will be influenced more by the nuances of an inevitably flexible sentence in a law of the sea convention than by the detailed guidance afforded by learned jurists for analyzing the consequences of the specific geographic circumstances before him.

The only issue seriously at stake that pertains to the substantive delimitation provisions is the prospect for timely completion and widespread

${ }^{105}$ ICNT/Rev.1, Arts. 57 and 76, respectively.

106 They apparently seek to place the burden of proof on the state opposing the application of equidistance. While they rely heavily on Article 6 of the 1958 Convention on the Continental Shelf (note 86 supra) in this regard, it is doubtful that that provision has this effect, since equidistance applies only "[i]n the absence of agreement, and unless another boundary line is justified by special circumstances."

${ }_{107}$ North Sea Continental Shelf cases, [1969] ICJ REP 3.

108 Id., Judgment, para. 101, at 54 . 
ratification of the convention on the law of the sea. No delimitation rule stated in the convention can be applied directly to a dispute between coastal states if one of them is not bound by the rule, either because it refuses to ratify the convention, or because it successfully insists on a right to reserve to the rule. Yet, experience with the Convention on the Continental Shelf suggests that even if a right to reserve is included, the substance of a delimitation provision may nevertheless discourage ratification by some states. It is particularly important that the conference try to avoid an approach to the delimitation problem that merely stimulates demands for reservations to the other clauses as well.

Since flexibility is common to all the proposals, and since the underlying differences relate to emphasis, there would seem to be little point in devoting much effort to a process that will inevitably result in the substitution of one flexible formula for another flexible formula. The purpose of including a substantive provision in the convention is to describe, and thereby to narrow, the range of choices available. Those who would emphasize equidistance are in effect arguing that the ICNT insufficiently narrows those choices. Their efforts may become self-defeating, however, if they press matters to the point where reservations become likely, since reservations not only broaden the choices of the reserving state but also make it less likely that a court will reach the conclusion that general international law imposes a narrow range of choices.

There was some discussion of means of indicating that the underlying question is essentially one of the relative emphasis to be accorded the various approaches to delimitation as they relate to particular circumstances and disputes. For example, a provision could be added to Articles 74 and 83 that expressly permits a state to file a formal declaration describing its position regarding the application of the principles referred to in paragraph 1 of those articles. Such a declaration would qualify the acceptance of those principles by a state, although it would not of course prejudice the position of any other state.

In his report, the chairman of Negotiating Group 7 also refers to the possibility of omitting any statement of the substantive rule and simply providing for delimitation in accordance with international law. ${ }^{109}$ Like the reservation approach, this one does not bind the parties to a specific statement of the governing principles, but like the declaration approach, it constitutes a conventional affirmation that substantive rules of international law govern and restrain the claims available in delimitation. ${ }^{110}$

\footnotetext{
109 Note 3 supra.

110 The chairman of Negotiating Group 7 also refers to the fact that the idea of the "equality of states" has been introduced in private discussion. Proceeding on the assumption that this idea is suggested in connection with the existing ICNT text on delimitation, several questions were nevertheless posed regarding the meaning of such a reference. Clearly, it cannot mean that every state receives an economic zone or continental shelf that is equal in size or value to the economic zone or continental shelf of its neighbors. Coming, as it does, from equidistance advocates, it cannot mean that delimitation is to be effected on a basis other than the geography of the area in question. Sovereign equality of states and equidistance have nothing to do with each
} 
It is regrettable that the conference is facing choices of this sort. The decision of the International Court of Justice in the North Sea Continental Shelf cases made it impractical to attempt to state the rule in the language of the Convention on the Continental Shelf. As is customary in the preparation of conventions of this sort, in drafting the basic rule for the original Single Negotiating Text, the chairman of the Second Committee (then Ambassador Galindo Pohl of El Salvador) looked to the language used by the International Court of Justice for guidance. ${ }^{111}$ The initial attack on this approach was made by a very few advocates of equidistance, mainly states with small islands that were at that time uncertain of the eventual outcome of negotiations regarding the provision on islands. ${ }^{112}$ That attack stimulated a measure of partisan enthusiasm for and hostility to the text that still plagues the conference but is in no sense merited by the substance of the language itself.

\section{Final Clauses}

For the first time, the conference engaged in intensive work on the final clauses of the convention. This work was concentrated in the Informal Plenary on Final Clauses chaired by the president of the conference. ${ }^{113}$ In addition, the Informal Plenary established a Group of L,egal Experts under the chairmanship of Ambassador Jens Evensen of Norway; it has referred issues to the group for drafting on which it has completed initial debate. $^{114}$ While the final clauses include provisions that are largely of a technical and essentially noncontroversial character, ${ }^{115}$ they also deal with matters that can affect the substance of the convention and international law, as well as matters that are politically controversial.

The president of the conference identified seven controversial items: amendment or revision, reservations, relation to other conventions, entry

other. It would therefore seem, at least to this author, that the underlying purpose must be to stress once again the notion that delimitation is to be effected on the basis of principles of law, and not the relative military or economic power of the states concerned. If this is the case, such a change would not seem to be worth stimulating demands for reservations among supporters of the existing text.

111 Informal Single Negotiating Text, UN Doc. A/CONF.62/WP.8 (May 7, 1975), Arts. 61 and 70, reprinted in 14 ILM 682 (1975). North Sea Continental Shelf cases, note 107 supra, Judgment, para. 101, at 53. The reference to the use of the median or equidistance line was added in the ISNT to the language used by the Court at that point.

112 The text of ICNT/Rev.1, Article 121 has remained the same since the original Single Negotiating Text. Opposition to the delimitation texts intensified after the requirement that the median or equidistance line should be applied provisionally was deleted in the Revised Single Negotiating Text (RSNT). Since the reason was that "the Conference may not adopt a compulsory jurisdictional procedure for the settlement of delimitation disputes" (RSNT, part II, Introductory Note, para. 12), it is not clear what role positions regarding dispute settlement played in this reaction.

113 Alternative texts and notes prepared by the Secretariat in 1976 tended to focus discussion. 6 OFF. Rec. 125 (1976).

114 Conf. Doc. FC/2 (July 27, 1979).

115 The Chairman of the Group of Legal Experts has submitted a text on these. Conf. Doc. FC/16 (Aug. 23, 1979). 
into force (including consideration of a preparatory commission), transitional provision, denunciation, and participation in the convention. ${ }^{116} \mathrm{He}$ pointed out that the existing ICNT contains provisions addressed to only two of these issues, namely, entry into force ${ }^{117}$ and the "transitional provision" that appears after the text. ${ }^{118}$

At the outset of the debate, the president stressed three objectives bearing on the preparation of final clauses:

Our prime concern is the establishment of a completely integrated legal order for the use of the oceans and its resources and potential. All else must be subordinated to and subserve this purpose. This is the function of the Preamble and the Final Clauses. They must not be allowed to create such contention as would obscure and obstruct the overriding objective, hamper the work of the Conference and imperil our chances of success.

We must seek to preserve intact, and protect, the efficacy and durability of the body of law which we are trying to create in the form of a Convention encompassing all issues and problems relating to the law of the sea as a package comprising certain elements that constitute a single and indivisible entity.

We must seek to attract the most extensive and representative degree of ratification and the earliest possible entry into force of the new Convention.

The second objective that I have specified here cannot be achieved if we expose the essential unity and coherence of the new body of law to the danger of impairment through the unrestricted exercise of the right of reservation.

We must seek to ensure for all States Parties to the Convention the highest attainable degree of clarity and certainty as to their rights and obligations under the Convention.

We must at the same time provide some measure of flexibility which would serve as an insurance against future erosion of the Convention and which would underpin rather than undermine the structure. ${ }^{119}$

While the Vienna Convention on the Law of Treaties ${ }^{120}$ had not yet entered into force, and in any event had not been ratified by a large majority of the states participating in the conference, it did constitute the point of departure for discussion and analysis of various problems. The issue discussed in many cases was whether it was desirable to provide for a result different from, or with more specificity than, that produced by the rules of the Vienna Convention applicable to a treaty that is silent on the point. It was generally recognized that the comprehensive scope of the law of the sea convention, including its constitutive aspects, necessitated some special treatment of these matters.

116 Conf. Doc. FC/I (July 23, 1979). $\quad{ }_{117}$ ICNT/Rev.l, Art. 301.

118 UN Doc. A/CONF.62/WP.10/Rev.1, at 139-40 (English).

119 Conf. Doc. FC/1, note 116 supra.

120 UN Doc. A/CONF.39/27 (1969), reprinted in 63 AJIL 875 (1969), 8 ILM 679 (1969). 


\section{Amendment or Revision}

The basic question posed on this subject was whether the convention should include procedures for amendment or a general review of its provisions, in addition to the review of the deep seabed mining regime contemplated in Article 155.121 It was pointed out that as a legal matter, protocols to the convention could be agreed by the parties at any time, and that either the parties or the UN General Assembly could call a conference if necessary at any time.

The question of primary juridical significance about provisions on amendments is whether an amendment may enter into force before it has been ratified by all the states parties. Many of the constituent elements of the overall consensus were specifically designed to accommodate the priorities of various minorities of states. Thus, the underlying balance and complex structure of the overall "package deal" could be altered if any of these elements could be changed without the assent of the affected minorities. This problem gave rise to suggestions that one might distinguish between technical and other amendments (including the first of several references to an expanded concept of jus cogens that will be addressed later in this discussion). It also gave rise to proposals for qualified majorities for all amendments to enter into force, including acceptance by diflerent groups for different parts of the convention. ${ }^{122}$

Of course, the possibility that an amendment might enter into force over the objection of a state party raises the fundamental question whether that state is bound by the amendment. There was support for the view that the amendment does not apply to that state's relations with other parties. ${ }^{123}$ While a possible, if less than desirable, substantive result in some cases, this approach presents structural difficulties in connection with the Seabed Authority and other institutions such as the Law of the Sea Tribunal. It was recognized that to the extent that an amendment must bind all parties or none, the basic choices are either to preclude the amendment from entering into force in the event of an objection or to expect that the objecting state might exercise its right to withdraw.

\section{Reservations}

The comments of the president of the conference ${ }^{124}$ foreshadowed substantial concern among delegations about the effect of reservations on

121 Conf. Doc. FC/4 (Aug. 1, 1979) contains the president's summary of the debate on amendment and revision.

122 One interesting idea would avoid the difficulty of identifying substantive groups by precluding entry into force of an amendment if a state previously declared that its substantial interests were directly affected and that it could not ratify the amendment. Any party could invoke the dispute settlement procedures of the convention to challenge the conclusion of the state that its substantial interests were directly affected. Conf. Doc. GLE/FC/10 (Aug. 23, 1979).

${ }^{123}$ See Vienna Convention on the Law of Treaties, note 120 supra, Art. 30, para. 4 (b) and Art. 40, para. 4.

124 See text accompanying note 119 supra. 
the integrity of the accommodations incorporated in the "package deal." There was no support for the idea that all articles of the convention should be subject to reservations. There also seemed to be little if any support for the option of remaining silent on the question of reservations. ${ }^{125}$

Even if it were agreed that the relevant rules of international law are those specified in the Vienna Convention on the Law of Treaties, the effect of omitting any clause on reservations would be unclear. The general rule in the Vienna Convention applicable to a treaty that does not deal with the issue is that a state may formulate a reservation unless that reservation "is incompatible with the object and purpose of the treaty." ${ }^{128}$ To interpret and apply the "object and purpose" criterion in the case of any given article of the vast and complex law of the sea convention would be exceedingly difficult, if not impossible.

The number of issues covered by the convention is legion, the differing priorities attached to them by different states almost infinite, and the number of states participating in the negotiation greater than ever before in history. It would in one sense be difficult to maintain that any particular reservation to any particular subparagraph of any particular article is contrary to the object and purpose of a huge convention of over three hundred articles and several annexes covering many subjects. On the other hand, it is likely that any attempt to achieve a consensus at the conference on the object and purpose of the convention would end, after a long period of time, with the verbatim repetition of almost every provision.

While a few delegations that have never been sympathetic to the convention did argue for liberal rules regarding reservations, it seems likely that the basic choice facing the conference is between a prohibition on all reservations and a prohibition on almost all reservations. As one may rightly deduce from the remarks of the president and almost all delegations over the years, the underlying object and purpose of the convention is not so much its substance as widespread agreement on a comprehensive regime for the oceans embracing all interests at stake. With few exceptions, if any, it is difficult to conceive of reservations compatible with that object and purpose. ${ }^{1: 27}$

1:5 Conf. Doc. FC/6 (Aug. 7, 1979) contains the president's summary of the debate on reservations.

1:6 Vienna Convention on the Law of Treaties, note 120 supra, Art. 19.

Reservations to the constituent instrument of an international organization require the acceptance of the competent organ of that organization. Id., Art. 20. How much of parts XI (deep seabeds), XV (settlement of disputes), and related annexes are covered by this rule? In the case of the Seabed Authority, what is the competent organ?

${ }^{127}$ In some instances, the positive benefit of promoting widespread ratification outweighs the substantive cost of permitting a particular reservation. As already noted, this category may include the substantive provisions regarding delimitation of the economic zone and continental shelf between states with opposite or adjacent coasts. 


\section{Relation to Other Conventions}

The question of relation to other conventions ${ }^{128}$ stirred some theoretical debate regarding the status of the 1958 conventions on the law of the sea after the entry into force of the new Law of the Sea Convention. ${ }^{229}$ This debate implicitly concerned the value of the 1958 conventions as evidence of customary international law. ${ }^{130}$

Another interesting question is posed by the need to refer to the relevant rules and principles of the law of the sea in the course of applying general multilateral conventions on other subjects. There was no dissent from the point that the establishment of the economic zone does not alter or relieve flag states or coastal states of their obligations under existing conventions regulating navigation and overflight beyond the territorial sea (without prejudice to coastal states' environmental rights under the new Law of the Sea Convention)..$^{131}$ In this connection it was noted, for example, that Article 12 of the Convention on International Civil Aviation, ${ }^{132}$ under which exclusively international regulations apply to civil aviation over the high seas, would continue to have exactly the same effect with respect to the exercise of freedom of overflight in the exclusive economic zone, despite the changes in terminology for the geographic areas in question..$^{133}$ It was also noted that the new Law of the Sea Convention should not: be regarded as altering the obligations of the parties to bilateral and multilateral treaties dealing with specific activities or areas.

\section{Entry Into Force}

Discussion of this item centered largely on the number of parties necessary for the convention to enter into force. ${ }^{134} \mathrm{~A}$ basic question raised was

${ }^{128}$ Conf. Doc. FC/7 (Aug. 9, 1979) contains the president's summary of the debate on relation to other conventions. See ICNT/Rev.1, Arts. 35(c), 51(1), 74(5), 83(4), 282 , and 283 in this connection.

${ }^{129}$ Virtually all of the provisions of the 1958 conventions are either repeated, modified, or replaced by the provisions of the ICNT/Rev.1.

${ }^{130}$ This matter will be discussed further in connection with the question of jus cogens.

${ }_{131}$ See Conf. Doc. GLE/FC/9 (Aug. 20, 1979).

132 Convention on International Civil Aviation, 1944, note 49 supra.

${ }^{133}$ See Conf. Doc. FC/7, note 128 supra. Two provisions of the IONT/Rev.1 are directed to this kind of problem. Article 58 preserves within the economic zone "the freedoms referred to in article 87 of navigation and overflight." Article 87 is the provision enumerating the freedoms of the high seas. Article 86, dealing with the application of the high seas provisions, is not a definition, and expressly states that it "does not entail any abridgement of the freedoms enjoyed by all states in the exclusive economic zone in accordance with article 58." The ICAO question was one of those that led to the adoption of the quoted terms. The author notes this point in $72 \mathrm{AJIL}$ at p. 69 and note 45 thereof in explaining them, referring generally to "insufficiently informed oral remarks of employees of certain nonmaritime specialized agencies" as one of the reasons for the clarification of the text regarding freedom of navigation and overflight in the economic zone.

134 Conf. Docs. FC/9 (Aug. 14, 1979) and FC/11 (Aug. 16, 1979) contain the president's summary of the debates on entry into force. 
whether the requirement should simply be quantitative, or should refer to particular categories of states as well. The relevance of the composition and voting structure of the Council of the Seabed Authority was noted in this regard.

There was widespread support for establishing a preparatory commission prior to the entry into force of the convention. Its principal responsibility would be to draft the initial rules, regulations, and procedures for deep seabed mining. It was emphasized that such a commission would have preparatory functions only and would not be an interim seabed authority with the power to conduct or authorize mining. ${ }^{135}$

The idea of permitting states to accept the convention provisionally was also discussed. ${ }^{136}$ While there were substantial doubts about this approach, it was widely agreed that should it be adopted, provisional acceptance would have to apply to the entire convention under the same conditions as permanent acceptance. The difference is that a state would cease to be a provisional party at such time as it decided not to become a permanent party. ${ }^{137}$

The main reason advanced for permitting provisional acceptance is that it would encourage more rapid and widespread acceptance of the convention. For some countries, some of the time-consuming formalities of permanent acceptance might not apply. For others, where the executive would not act alone, the need for provisional approval only might facilitate consideration of the convention and help significantly to overcome fears of the unknown that could prevent its permanent acceptance.

\section{Denunciation}

The question of denunciation did not stimulate extensive debate..$^{138}$ Among the grounds proffered for denunciation were the entry into force of binding amendments or regulations over the objection of a state. The general view was that every state retained the sovereign right to withdraw from a convention of this sort, although such withdrawal would not affect its obligations under customary international law. ${ }^{139}$ Reference was made to the declaration of the San Francisco Conference confirming the right to withdraw from the United Nations despite the absence of a Charter provi-

135 Conf. Docs. FC/8 (Aug. 13, 1979) and FC/8/Add.1 (Aug. 10, 1979) contain a Secretariat study of instruments establishing preparatory bodies. It will be considered at the start of the next session.

${ }^{136}$ The Secretariat recirculated its study of provisional application, UN Doc. A/AC. 138/88 (June 12, 1973).

${ }_{137}$ During the discussion of ratification in the Group of Legal Experts on Final Clauses, it was pointed out that signature alone would not bind a state to the provisions of the treaty, and that the principle of Article 18 of the Vienna Convention on the Law of Treaties (note 120 supra) would not have either this effect or the effect of impairing the rights and obligations of states under the existing international law of the sea and treaties.

${ }_{13} \ngtr$ Conf. Doc. FC/13 contains the president's summary of the debate on denunciation. 139. See Vienna Convention on the Law of Treaties, note 120 supra, Art. 43. 
sion on the subject. ${ }^{140}$ A general view seemed to be emerging that a specific provision on denunciation should be included.

\section{Jus Cogens}

One of the novel aspects of the discussion of final clauses was the introduction of the concept of jus cogens. As used in the Vienna Convention on the Law of Treaties, the concept refers to a peremptory norm of international law that voids any inconsistent treaty. ${ }^{141}$

When informal debate on final clauses was being organized, representatives of the Group of 77 indicated that certain of its members wished to have "ius cogens" added to the list of issues. It was understood that debate on the matter would be permitted. As might be expected, references to jus cogens in the course of discussion of final clauses were rarely confined to the concept as it is understood and used in the Vienna Convention, since it is questionable whether a treaty provision can, as such, create a rule of jus cogens in that sense. ${ }^{142}$

Jus cogens was mentioned in connection with three distinct questions. The first was whether to prepare an article that would identify principles or provisions that would not be subject to amendment or reservations; the entrenched concepts governing the deep seabed review conference under Article 155 were cited as an example. The second was whether an amendment or reservation would be effective (at least with respect tc an objecting state) if the convention were silent on amendment and reservations. The third, perhaps the most subtle, explored whether provisions of the law of the sea convention would be regarded as declaratory of international law.

Because it may be argued that subjecting a provision to reservations, and perhaps amendment, weakens the case for regarding it as declaratory of international law, there is a reluctance to permit reservations or easy amendment that transcends the effect on the convention as a treaty. Indeed, the psychological impact of the arguments advanced by the International Court of Justice to distinguish between the lawmaking character of Articles I to 3 of the Convention on the Continental Shelf and the contractual character of Article 6 of that convention has been substantial. ${ }^{143}$ The widespread use of cross-references in the ICNT is designed to discourage a court from concluding that a general provision is declaratory of international law while the details that made agreement on that provision possible are not. It is conceivable that many states would sooner see the conference fail than permit a text to emerge that allows reservations in connection with priority provisions they regard, or plan to regard, as declaratory of international law. One ingenious argument made by a prospective seabed mining state against permitting provisional application of the convention was that it was incom-

140 Doc. 1210, P/20, I UNCIO Docs. 612, 615-17, 619-20 (1945).

141 Vienna Convention on the Law of Treaties, note 120 supra, Arts. 53 and 64.

142 It can be argued that even Article 103 of the UN Charter as such binds only UN members.

143 See North Sea Continental Shelf cases, [1969] IC] REP. 28-42, paras. 37-72. 
patible with the status of the substantive provisions, other than those dealing with the deep seabeds, as new customary law.

As already noted, the question of the relationship between the new convention and the 1958 conventions is in essence another aspect of the customary law question. The strictly legal point that, to the extent they are inconsistent, the new convention supplants the old conventions as between the parties to both was not contested, and was not really the issue. At the start of the law of the sea negotiations, a leading coastal state participant said, "I come to bury Grotius, not to praise him." This spirit informs revived attempts to reduce if not eliminate the value of the 1958 conventions as evidence of customary law and substitute the new convention for them ( which, incidentally, seems in the end to provide a more solid foundation for preserving high seas freedoms under modern conditions). As a consensus nears on the noninstitutional parts of the ICNT that are amenable to implementation without a treaty, and as more and more of these provisions become the basis in fact for state practice, there is considerably less resistance to the idea. Needless to say, nothing the convention text says can make it declaratory of customary law, but evidence of the intent of the conterence may be relevant.

The question of the relationship between the law of the sea convention and subsequent inconsistent agreements among some of the parties presents the same issue dealt with in Article 103 of the UN Charter. It closely resembles the concept of $j u s$ cogens as presented in the Vienna Convention, but is in fact a question of modifying obligations under multilateral treaties between certain parties only. Article 41 of the Vienna Convention precludes such modifications if they affect the other parties' rights or are incompatible with the effective execution of the object and purpose of the treaty as a whole. This question has been raised in a proposal by Chile ${ }^{144}$ that attempts to make the principle of the common heritage of mankind a true peremptory norm of international law, rendering conflicting agreements invalid. As a practical matter, it seems highly unlikely that states, while parties to the law of the sea convention, would expose themselves to the sanctions available under the convention by entering into subsequent conflicting agreements regarding seabed mining.

One may also ask whether there is any sense in having a major theoretical argument over the issue. A peremptory norm of international law must in the first place be a norm of international law. Were the states principally interested in deep seabed mining to find the implementation of the treaty regime intolerably incompatible with their expectations, and withdraw and proceed with mining on a different basis, an assertion that they are violating customary international law would have the same significance

1*4 Conf. Doc. FC/14 (Aug. 29, 1979) proposes the following text:

The States Parties to the present Convention accept and recognize on behalf of the international community as a whole that the provision relating to the common heritage of mankind set out in article 136 is a peremptory norm of general international law from which no derogation is permitted and which, consequently, can be modified only by a subsequent norm of general international law having the same character. 
whether or not the convention contains a clause such as that proposed by Chile. ${ }^{145}$

Should it come to pass that Chile is not persuaded by such arguments or loses control of its proposal, the addition of a veritable Christmas treeful of ornaments seems possible. What are the implications of declaring the principle of the common heritage a peremptory norm of international law, but not the principle of the sovereign rights of the coastal state over the natural resources of the economic zone or the continental shelf? What of the freedoms of navigation and overflight, or the obligation to protect and preserve the marine environment? In the end, something close to a table of contents of the convention might emerge, as occurred in the discussions of such matters during the debate on amendments. ${ }^{148}$ Would this result be any different from relying on the rules in Articles 41 and 43 of the Vienna Convention?

\section{Participation and the Transitional Provision}

The discussion of participation in the convention, presumably including the right to become a party with the same rights and duties as all other parties, proved to be exceedingly politicized. ${ }^{14}$ While it is generally accepted that all states would be permitted to become parties to the convention, and that the "all states" clause would be administered by the United Nations in the same manner as with respect to other treaties, various proposals were also made to permit other entities to become parties, including: the European Economic Community and similar regional economic communities; ${ }^{148}$ fully self-governing associated states that choose that status in

145 It should be noted that an interpretation of the common heritage principle that takes adequate account of the world's needs for raw materials at reasonible prices and the interests of developing countries in deriving financial benefits from deep seabed mining might well preclude restrictive commodity agreements affecting the supply, marketing, or prices of any metal mined from the deep seabeds.

146 See Conf. Doc. FC/4 (Aug. 1, 1979).

147 Conf. Docs. FC/13 (Aug. 20, 1979) and FC/17 (Aug. 23, 1979) contain the president's summary of the debates on participation in the convention.

148 Conf. Doc. FC/5 (Aug. 3, 1979), repeating the text in UN Doc. A/CONF.62/ L.32 (Sept. 14, 1978).

Utilization and conservation of living resources, some aspects of the proposed deep seabed mining regime, protection of the marine environment, and potentially transport and energy have been mentioned as matters within the competence of the EEC for these purposes. Koers, Participation of the European Economic Community in a New Law of the Sea Convention, 73 AJIL 426 (1979). With respect to the Seabed Authority, Koers notes that EEC participation "in the Assembly (and other organs) will, of course, require special voting arrangements." $I d$. at 434 . Were this a reference to the Council, it would certainly be an understatement. Current approaches would give each Council member one vote and rely on the number of vote.s necessary to prevent action as the basis for protecting seabed mining and consumer interests. The "blocking" numbers discussed proceed on the assumption that seabed mining and consumer states that are members of the EEC would qualify and vote separately.

An informal proposal by the USSR (Conf. Doc. FC/3 (July 30, 1979)) takes a more general approach to the question of international organizations with competence 
an act of self-determination supervised and approved by the United Nations and that have full legal and administrative competence regarding the subject matter of the convention (i.e., the Cook Islands and Niue supported by New Zealand, the state with which they are associated); ${ }^{149}$ the Trust Territory of the Pacific Islands; ${ }^{150}$ any territory that has not attained full independence in accordance with Resolution 1514 (XV) of the General Assembly; ${ }^{151}$ any national liberation movement recognized by the United Nations and the regional intergovernmental organization concerned..$^{152}$

The first two of these can be viewed as special problems of applying the "all states" concept. It might be possible to permit such entities to accept the convention in connection with an all states clause, since both are exercising the competence of states in their stead.

Some careful work will be required to ensure that any arrangements in this regard do not permit a state to enjoy the benefits of a party with respect to some matters covered by the convention, but without assuming the obligations entailed in other parts of the convention. If an economic community may become a party only with respect to matters within its competence, a serious question arises as to whether it should be permitted to exercise the rights of a party with respect to areas and nationals of a member state that has not assumed the obligations of the convention for matters that are not within the competence of the community. The question is a variant of the problem of reservations.

In this connection, the European Court of Justice has said:

It is further important to state, as was correctly pointed out by the Commission, that it is not necessary to set out and determine, as regards other parties to the Convention, the division of powers in this respect between the Community and the Member States, particularly as it may change in the course of time. It is sufficient to state to the other contracting parties that the matter gives rise to a division of powers within the Community, it being understood that the exact nature of that division is a domestic question in which third parties have no need to intervene. In the present instance the important

in matters dealt with by the convention. It provides:

1. If an international organization established by States conducts activities in one or several spheres regulated by the provisions of this Convention, references to States in the corresponding provisions of the Convention shall be deemed to apply to such an organization, on condition that it declares its acceptance of the rights and duties provided for in this Convention.

2. States Parties to this Convention which are members of such an organization shall take all appropriate steps to ensure that the organization makes a declaration in accordance with the preceding paragraph.

Compare Art. 22, Convention on International Liability for Damage Caused by Space Objects, 1972, 24 UST 2389, TIAS No. 7762.

149 Conf. Doc. FC/10 (Aug. 15, 1979).

150 Statement and Informal Proposal of the Federated States of Micronesia (Aug. 23, 1979).

151 Conf. Doc. FC/12 (Aug. 16, 1979). 152 Ibid. 
thing is that the implementation of the Convention should not be incomplete. ${ }^{153}$

The question of the Trust Territory of the Pacific Islands is largely resolved by the anticipation that associated states ${ }^{154}$ will emerge with the necessary internal and external competence to become parties upon termination of the Trust.

The most serious controversy surrounds the last two kinds of entities. The problem of dependencies also arises in the context of the so-called transitional provision. ${ }^{155}$ That provision states that resource rights of various dependent territories or territories under foreign occupation or colonial domination "shall be vested in the inhabitants of that territory, to be exercised by them for their own benefit." A "metropolitan or foreign power . . . may not in any case exercise, profit or benefit from or in any way infringe" these rights. In addition, in cases of a dispute over the sovereignty of a territory, if the United Nations "has recommended specific means of solution," these rights "may not be exercised except with the prior: consent of the parties to the dispute." 158

While large numbers of delegations are required for political reasons to make positive statements on dependencies and liberation movemients for the record, it is generally understood at the conference that their inclusion could wreck the prospects for ratification of the convention. Whether there is anything to be gained from pressing the issue might be analyzed by examining some of the main objectives that may be involved: legal rights as parties to the convention, protection of the inhabitants of dependencies and occupied territories, and political recognition.

Two distinct questions are involved. First, what state is internationally responsible in fact for ensuring compliance with international law (including the convention) in the offshore areas in question? Second, what are its special duties as regards the present and future interests of the inhabitants? If one approaches the matter in terms of who should be in control of an area rather than who is in control, both of these questions become irrelevant. The only question then is whether it is considered desirable to prejudice the effective entry into force of the convention.

Seen in this context, exercising the legal rights and having the legal duties of a party to the convention becomes a problem only in a few cases where the relationship with a state is so distinctive, and the independent powers of the dependency over its territory so extensive, that a serious practical question of which entity should exercise the rights and duties under the

${ }^{153}$ Ruling on Participation of Member States of European Atomic E'nergy Community in Convention Relating to Physical Protection of Nuclear Materials in Absence of Concurrent Participation of the Community, 21 O.J. Eur. Comm. (No. C 302) para. 35 (1978), 18 ILM 85, 101 (1979).

${ }^{154}$ Outside the Mariana Islands.

${ }^{155}$ Conf. Doc. FC/11 (Aug. 16, 1979) contains the president's summary of the debate on the transitional provision.

156 The transitional provision was removed from the treaty articles in the RSNT. It was Article 136 of the SNT. 
convention arises in the opinion of both the state and the dependency. The primary objective seems to be the independent exercise of legal rights with respect to coastal resources, especially in the economic zone and on the continental shelf. In these special cases (e.g., the associated states that will emerge in Micronesia after termination of the Trust, the Cook Islands, and Niue) the three common elements are: an independent local government actually exercising comprehensive territorial competence over matters dealt with by the convention, external competence of that government to enter into international agreements on such matters, and recognition of such internal and external competence by the state with which that government is associated. Two theoretical options arise in such cases: to treat such associated states as parties with respect to some matters (e.g., coastal state rights and duties), or to treat them as parties with respect to all matters (including "Hags" and membership in the Seabed Authority).

As for liberation movements, the underlying objective seems to be to enhance their political recognition. They cannot, and apparently do not wish to, claim economic zones, mine the seabeds on their own, sail ships under their flag, and so forth, ${ }^{157}$ at least until they form governments-at which point the legal issue becomes one of recognition of states and governments, not one of liberation movements. Indeed, a liberation movement would presumably refuse to concede that it might not yet be a national government by the time there are substantial revenues generated from deep seabed mining. In brief, there is no substantial legal point related to the convention in pressing the issue of permitting liberation movements to become parties to it.

The fact that the latest proposal on liberation movements is couched in terms of accession rather than signature suggests a refined appreciation of the problem. ${ }^{258}$ Be that as it may, the real problem is that the law of the sea convention cannot be the testing ground for new and controversial developments on the issue. The attempt could wreck the conference; victory could wreck the convention. To put it mildly, the idea of requiring formal recognition of or a commitment to finance certain liberation movements as the price for a law of the sea convention substantially miscalculates the political equation.

Of course, the advocates of permitting liberation movements to become parties may be making an underlying point-unrelated to the law of the sea convention as such-regarding the lawfulness of the physical control being exercised over the land territories sought to be liberated. This question is of the same genre as that adverted to for disputed areas in the proposed transitional provision. It is not a law of the sea question at all; in-

${ }_{157}$ The basic juridical provisions refer, necessarily, to states. "Among the relevant provisions cited were articles $2,3,17,21,24,25,33,38,41,42,47,49,53,54$, $56,60,61,62,70,73,74,76,77,83,87,90,91,94,105,106,107,125,130,153$, $156,159,161,192,193,194,211,217,218,220,226,228,234,235,245,246,279$ and 287 of the ICNT/Rev.l." President's Note, Informal Plenary on Final Clauses, Conf. Doc. FC/17 (Aug. 23, 1979), para. 2.

15: Conf. Doc. FC/12 (Aug. 16, 1979). 
deed, the law of the sea aspect derives completely from the piosition taken regarding land territory. States that do not recognize the validity of claims to or occupation of territories may maintain the same position regarding claims of right under the convention in respect of those territories (e.g., territorial sea, continental shelf, or economic zone claims).

The basic problem appears to be common to all areas arguably under "foreign" control: the use, allocation, and depletion of natural resources off the coast of dependencies or areas under military occupation. (At least one of the above rubrics presumably covers "foreign"-controlled "disputed areas," as well as areas sought to be freed by the relevant national liberation movements.)

It seems fruitless to approach this issue in terms of who has the right to supervise (administer) resource activities. It is the fact of "foreign" or "metropolitan" administration on the coast, whether lawful or not, that gives rise to the problem. The practical question is: even if its presence is lawful, what are the obligations of a foreign or metropolitan power regarding local inhabitants? No obligations can be imposed in practice if their effectiveness is dependent upon an admission by a power that its claim and presence are illegal.

In the case of military occupation, it seems clear that the traditional protections afforded inhabitants by international law and the Hague and Red Cross Conventions should apply to offshore resources of the coastal state. These rules impose very substantial limitations on the occupying power. ${ }^{150}$ For dependencies, the requirements of existing international law may be different, but they are no less solemn. The language of chapter XI of the UN Charter seems more protective of the inhabitants and is free of the legal problems of the proposed transitional provision. ${ }^{160}$

The convention need say nothing at all to preserve these protections under the Charter and other rules of international law. This is made abundantly clear by the preamble of the ICNT, ${ }^{161}$ not to merition Article 103 of the Charter. Indeed, several legal problems would be created by treating the matter in the convention itself.

If the conference attempts to state the applicable substantive rules, it runs the risk of dividing and confusing another body of international law.

159 The application to continental shelf resources of the relevant restraints of international law on the occupying power is not contested. See U.S. Dept. of State, Mernorandum of Law on Israel's Right to Develop Oil Fields in Sinai and the Gulf of Suez (Oct. 1, 1976), 16 ILM 733 (1977). Israel's response, while differing on the effect of the relevant rules, states: "The duty of an occupant is inter alia to maintain economic prosperity of occupied territory." While "reasonable exploitation" is in its view permitted, "waste or excessive extraction" are not. Ministry of Foreign Affairs Memorandum of the Law on the Right to Develop New Oil Fields in the Sinai (Aug. 1, 1977), 17 ILM 432, 443 (1978).

160 Some of the problems are discussed in 69 AJIL (1975) at pp. 786-87 (regarding SNT Art. 136).

161 The last preambular paragraph of the ICNT/Rev.1 affirms that "the rules of customary international law continue to govern matters not expressly regulated by the provisions of this Convention." 
In order to avoid leaving something out, it must either draft beyond its expertise (and mandate) or make a general cross-reference to international law. This also raises the possible implication that these other rules of international law would apply offshore only by virtue of, or to parties to, the law of the sea convention. Since fisheries zones and continental shelves already exist, and problems may arise before the convention enters into force, that is an undesirable result.

In addition, it should be noted that the interpretation and application of any such clause would inevitably involve very sensitive political issues. For example, how many states would delegate to the UN General Assembly the power to determine whether part of what they consider their territory is in reality, at least for purposes of the convention, an area under foreign occupation or colonial domination? With respect to judicial or arbitral consideration of such matters, it is instructive to note the strong resistance to the ICNT requirement for adjudication or arbitration even of offshore boundaries, and the fact that even though the ICNT would require some third-party procedure on offshore delimitation entailing a binding decision, it provides that "such procedure or decision shall exclude the determination of any claim to sovereignty or other rights with respect to continental or insular land territory." 162

Thus, inclusion of a clause on this subject would inevitably produce demands for an exclusion from compulsory third-party dispute settlement procedures and a right to reserve to the clause. Such demands would threaten a broader reopening of the question of exceptions to dispute settlement and would hinder attempts to limit reservations generally. If, as seems likely, reservations would be the end result, inclusion of a clause accomplishes nothing as a matter of treaty law and casts doubt upon its value as evidence of customary law.

\section{Conclusion: Prospects for the Ninth Session}

The three major obstacles that must be overcome to achieve a treaty are the remaining unresolved deep seabed mining issues, including voting in the Authority; the politically inspired proposals regarding dependencies and national liberation movements; and the pitfalls of formal procedures. A significant testimony to the extraordinary progress made by the conference is that the second and in some measure the third of these have nothing to do with the substance of the law of the sea and involve problems wholly extraneous to it. Nevertheless, only a considerable and probably enhanced determination by important conference leaders to resolve the problems and to protect the convention from slow but mortal unraveling is likely to overcome these obstacles and to see the conference through to a successful conclusion in the year or so envisaged. Those who have relaxed and enjoyed the fray for so long on the assumption that the ICNT is already international law should take serious note of the fact that there are now voices calling it only a stage in the development of the law that should be followed by new,

${ }^{16 \%}$ ICNT/Rev.1, Art. 298, para. 1(a). 
inconsistent unilateral actions, such as demands that requests be made of coastal states for permission to navigate in the economic zone. ${ }^{103}$

It is difficult to deal with the view that, in the end, this prccedurally innovative, informal, marathon conference must formally adopt texts according to the procedures sanctified by tradition and its Rules of Procedure. Some holding this view participated in other conferences where formal procedures such as voting on individual amendments and articles both in committee and plenary were in fact employed. Others have spent much of their careers working on resolutions of the UN General Assembly rather than legally binding treaties that must be submitted to governments for ratification. Yet the emphasis on the integrity of the "package deal" that dominated the debate in the Informal Plenary on questions such as amendments to the convention after ratification must also be maintained during the formal stages of the conference. ${ }^{104}$ Without doubt, the Rules of Procedure ${ }^{105}$ must be respected; but that includes the gentleman's agreement on consensus procedures. ${ }^{166}$

To produce a widely acceptable law of the sea convention, there will have to be a working consensus on the final informal text (subject perhaps to additional scrutiny by the Drafting Committee). That final informal text will have to become the Convention on the Law of the Sea, no matter how many intermediate stages it passes through along the way. There could no longer be any changes of substance that affect the consensus.

Voting on individual amendments, individual articles, or even individual parts risks destroying the convention. Admittedly, the danger of voting on amendments is greater in committee than in Plenary, ${ }^{107}$ and the danger of

163 This theme was resoundingly pressed by three distinguished Nova Scotia lawyers, Professors Gold, Flemming, and Johnston, at the 13th Annual Meeting of the Law of the Sea Institute in Mexico City in October 1979. Their remarks will be published in the Proceedings. These lawyers-albeit unwittingly-have posed fundamental questions about the willingness of informed members of the Canadian public to support the integrity of the Canadian side of the massive and revolutionary bargains on both freedom of navigation and coastal state pollution controls struck with the rest of the world. The broader question is the conclusion states will draw about the possibilities for serious negotiation in the future.

164 The procedural and substantive implications of the "package deal" approach to the negotiations are the subject of an illuminating essay by the leader of the French delegation, Guy Ladreit de Lacharrière, in Aspects juridiques de la négotiation sur un "package deal" à la Conférence des Nations Unies sur le droit de la mer, in Essays IN Honor of ErTK Castrén (Publications of the Finnish Branch of the International Law Association No. 2, Helsinki 1979).

165 Note 14 supra.

${ }^{166}$ Appended to the Rules of Procedure, reprinted in 73 AJIL 3 n.11 (1979).

${ }^{167}$ In a main committee, a determination that all efforts at consensus have been exhausted can be made, and an amendment can be adopted, by a majority of those present and voting; the "cooling-off period" during which a vote can be deferred is 5 days. Rules of Procedure, note 14 supra, rule 55. In Plenary, the requisite raajority is two-" thirds of those present and voting, provided that majority includes at least a majority of the states participating in that session of the conference (something on the order of 75 affirmative votes at a minimum); the "cooling-off period" is 10 days. Rules 37 and 39. 
voting on articles may be greater than the danger of voting on amendments. Since the informal texts are plenary documents issued on the joint responsibility of the president and the chairmen, it would make sense to concentrate formal proceedings in the Plenary, at least insofar as any decisions are concerned. ${ }^{168}$ But still, the very idea of voting is fundamentally incompatible not only with the concept of consensus but with the preservation of the "package deal" and the view that the noninstitutional aspects of the convention are the most authoritative evidence of modern international law.

This approach has been questioned on the ground that the absence of records regarding the substantive negotiations makes it difficult for delegations to convince their governments or domestic public opinion that they have in fact made every effort to achieve changes in the text, and have not succeeded. However, politically astute groups able to bring substantial pressure to bear on their delegations are probably well aware of the fact that the time for making maximum efforts for changes is prior to completion of an informal text, not afterwards. Accordingly, the main function of the tormal stage of the conference would seem to be to afford an opportunity for states to record their preferences and disappointments. Even such a procedure has the inherent danger of stimulating exchanges on questions of interpretation that could undermine the fragile agreements of which the overall consensus is composed. It was suggested that delegations be encouraged to circulate their statements in writing rather than deliver them orally.

The "balance" of the convention is so delicate, and the web of implicit bargains and complex relationships so opaque, that any attempt to take serious action on the premise that no article has been agreed would surely prove as destructive as it is naive. The only sure defense against the various risks that will arise during formal proceedings is the existence of a large enough group of sophisticated delegations that is prepared, as a matter of principle, to oppose every procedural or substantive proposal that could upset the consensus. The strength, skill, and discipline of that "escort"-its ability to forestall or defeat any action, of whatever inherent merit, that might damage its charge-will determine the outcome.

168 The conference has provided for negotiations in Plenary in which the president would have the chairmen of the 3 main committees associated with him on the podium. UN Doc. A/CONF.62/62, note 5 supra, para. II(14). 